\title{
Spatio Temporal Analysis of Land Use Change for Supporting Landslide Exposure Assessment
}

\author{
Anung Kurniawan, B.G.C.M (Bart) Krol
}

Received: 03072014 / Accepted: 18072014 / Published online: 31122014

(c) 2014 Faculty of Geography UGM and The Indonesian Geographers Association

\begin{abstract}
Located in landslide prone areas, Cipanas and Pacet sub-districts are placed in areas where land uses are very dynamic. Land use change analysis is needed in these sub-districts for assessing its pattern and the driving factors that caused the change. Moreover, the results from the analysis can be used as input for land use change modeling to predict land use in the future for supporting landslide exposure assessment. The objective of this research is to assess spatio temporal dynamic of landslide exposure by integrating land use change modeling using CLUE-S and landslide exposure assessment. The obtained Kappa value was classified as high agreement. Future land use prediction was conducted by considering three scenarios, baseline scenario (no restriction), scenario 1 (restriction in conservation area), and scenario 3 (restriction in conservation area and landslide prone area). Result of future land use prediction year 2031 in baseline scenario dominated by settlement and infrastructure expansion and forest conversion into another land use. However, implementation of scenario 1 and 2 in the model, were successfully restricts forest conversion and development of settlement and infrastructure in landslide prone area. Landslide exposure assessment was conducted by combining weighted asset map and landslide susceptibility map. There were two type of asset considered in this research, social and physical asset. Population density was applied as a factor for social asset, while land use was applied as a factor for physical asset. Weight of assets and their factors was determined based on experts opinion by using Analytic Hierarchy Process (AHP) approach. The result landslide exposure assessment shows that high and medium landslide exposure area follow pattern of settlement and infrastructure land use. Future landslide exposure assessment by considering baseline scenario resulted in the increasing of high landslide exposure area in year 2031. On the other hand, by applying restriction in scenario 1 and 2, high landslide exposure can be reduced.
\end{abstract}

Keywords: Landslide perception, coping strategies, risk governance framework

Abstrak Terletak di daerah rawan longsor, kecamatan Cipanas dan Pacet berlokasi di daerah di mana penggunaan lahan yang sangat dinamis. Analisis perubahan penggunaan lahan yang dibutuhkan di daerah ini untuk menilai pola dan faktorfaktor pendorong yang menyebabkan perubahan tersebut. Selain itu, hasil dari analisis dapat digunakan sebagai masukan untuk pemodelan perubahan penggunaan lahan untuk memprediksi penggunaan lahan di masa depan untuk mendukung penilaian paparan longsor. Tujuan dari penelitian ini adalah untuk menilai dinamika spasiotemporal paparan longsor dengan mengintegrasikan perubahan penggunaan lahan pemodelan menggunakan CLUE-S dan penilaian paparan longsor. Prediksi penggunaan lahan dilakukan dengan mempertimbangkan tiga skenario, skenario baseline (tidak ada pembatasan), skenario 1 (pembatasan dalam kawasan konservasi), dan skenario 3 (pembatasan dalam kawasan konservasi dan daerah rawan longsor). Hasil penggunaan lahan prediksi tahun 2031 dalam skenario awal didominasi oleh pemukiman dan perluasan infrastruktur dan konversi hutan menjadi lahan lain. Namun, pelaksanaan skenario 1 dan 2 dalam model, berhasil membatasi konversi hutan dan pengembangan permukiman dan infrastruktur di daerah rawan longsor. Penilaian paparan longsor dilakukan dengan menggabungkan peta aset tertimbang dan longsor kerentanan peta. Ada dua jenis aset dipertimbangkan dalam penelitian, aset fisik dan aset sosial. Kepadatan penduduk diterapkan sebagai faktor untuk aset sosial, sementara penggunaan lahan diterapkan sebagai faktor untuk aset fisik. Berat aset dan faktor mereka ditentukan berdasarkan pendapat ahli dengan menggunakan Analytic Hierarchy Process (AHP). Penilaian paparan Hasil longsor menunjukkan bahwa pola mengikuti daerah paparan longsor tinggi dan menengah pemukiman dan prasarana guna lahan. Masa mendatang penilaian paparan longsor dengan mempertimbangkan skenario baseline menghasilkan meningkatnya daerah paparan longsor yang tinggi pada tahun 2031. Di sisi lain, dengan menerapkan pembatasan dalam skenario 1 dan 2, paparan longsor yang tinggi dapat dikurangi.

Kata kunci: persepsi longsor, strategi mengatasi bencana, kerangka pengelolaan risiko

Anung Kurniawan

Dit.BPTH Kementrian Kehutanan

email: anung kurniawan@yahoo.com

B.G.C.M (Bart) Krol

Faculty of Geo-information Science and Earth Observation, University of Twente, the Netherlands

\section{Introduction}

Despite the fact that landslides can be triggered by rainfall, earthquake or volcanic eruption, increasing development into the hillslope areas caused by pressure of raising population and urbanization become important factors that induced landslides occurrence. It is because the human activities such as deforestation, excavation of slopes for road cuts and building sites 
in landslide prone areas [Dai et al., 2002]. Thus, the activities will increase areas which are exposed to landslide.

In landslide prone areas, land use change might increase exposure of particular areas related to landside occurrences. This exposure comprises of physical, social, economical, and environmental assets or in other word the elements at risk [Cammerer et al., 2012; Pellicani et al., 2013]. Furthermore, these assets need to be assessed in order to know the level of exposure in landslide prone areas.

In order to reduce the impact of landslides, there are strategies which can be applied through planning and management [Dai et al., 2002]. One of them is spatial planning application, for example by applying development restriction in the landslide prone area. However, in real condition, it will need time to know the impacts of the policy application in the future. Therefore, land use model can be applied to understand these impacts for land use management in the area exposed to landslide. Furthermore, by applying land use scenario in land use modeling, it will support the assessment of potential future land use developments prior to negative changes in areas at risk occur [Verburg et al. 2004; Cammerer et al., 2012].

Bappeda Cianjur [2011] stated that almost all of sub-districts in Cianjur regency have landslide prone areas. In the northern part of this regency, there are two sub-districts which have many landslide occurrences, namely Cipanas and Pacet. Almost every year, there were landslide occurrences in these sub-districts [BPBD Cianjur, 2012]. The most recent big landslide occurred in 9 January 2013, located in Cipanas sub-district, where the material that closed national road resulting in traffic disruption [Metrotvnews, 2013].

While Cipanas and Pacet sub-districts are located in landslide prone area, they are also centre of agricultural production, large population and famous tourist destination [Bappeda Cianjur, 2011; BPBD Cianjur, 2012]. Although the areas are centre of agricultural production, there is a trend in land use change from agricultural land to settlement and commercial area [Hesaki, 2012]. Furthermore, because of limited land resources, the development has been utilizing areas with steep slopes which are prone to landslide occurrence in the hilly area [Bappeda Cianjur, 2011].

Land use change analysis is needed in these subdistricts for assessing its pattern and the driving factors that caused the change. Moreover, the results from the analysis can be used as input for land use change modeling to predict land use in the future for supporting landslide exposure assessment. By applying scenario in the modeling process, it will be useful to recognize impact of different policies to the existence of exposed area to landslide for improving land use management and spatial planning in these areas.

\section{The Methods}

This research was conducted in North-West part of Cianjur regency, which consist of Cipanas and Pacet Sub-district. Actually, Cipanas sub-district was part of Pacet sub-district. In order to support regional development in the area, they were separated in year 2003. Geographically, the study area located between

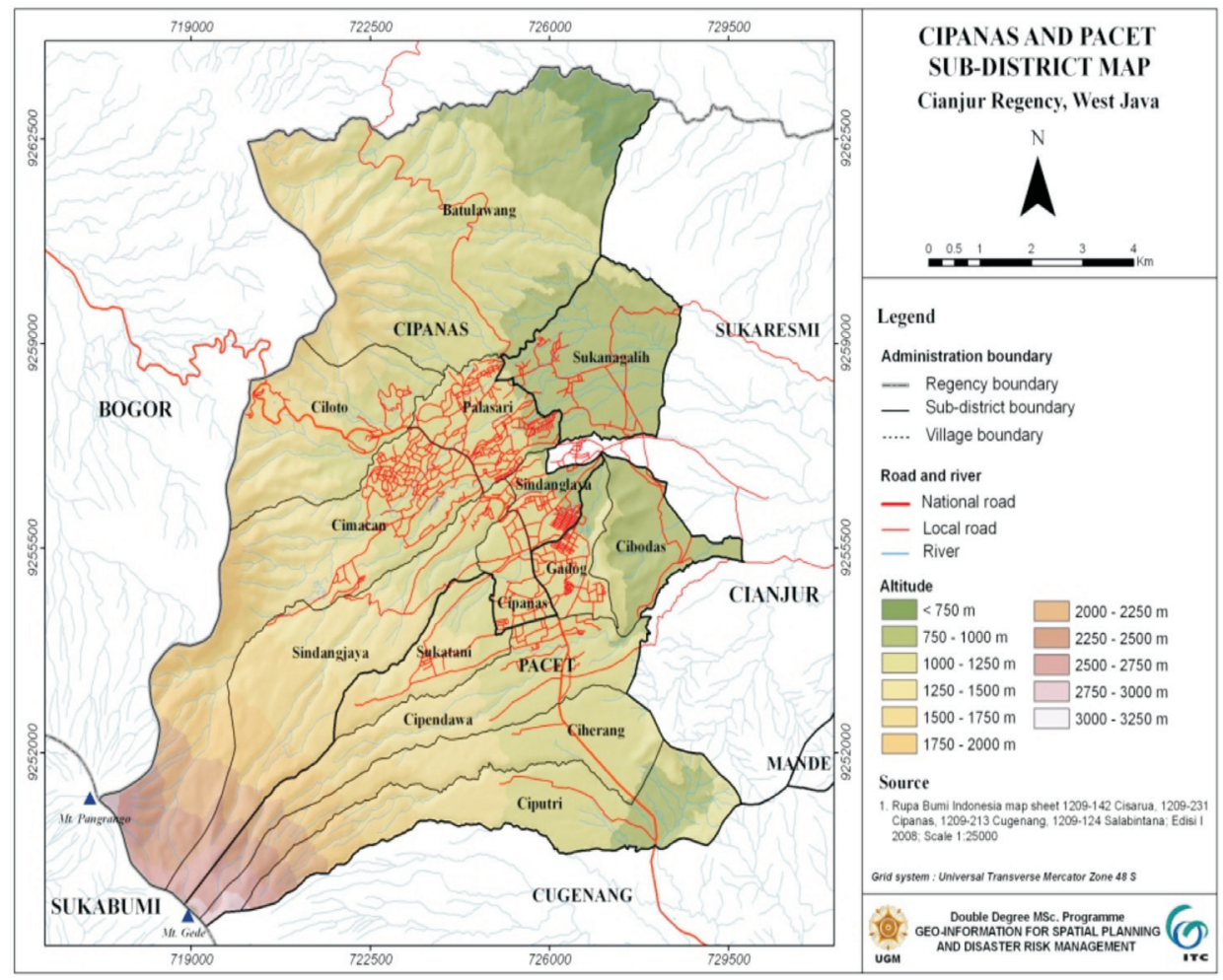

Figure 1. Map of the Study Area 
$106^{\circ} 57^{\prime} 54^{\prime \prime}-107^{\circ} 04^{\prime} 43^{\prime \prime} \mathrm{E}$ and $6^{\circ} 39^{\prime} 23^{\prime \prime}-6^{\circ} 47^{\prime} 23^{\prime \prime} S$ with an area of 10,873.8 Ha. Figure 1 shows map of the study area.

There were three Landsat imageries which used to obtain land use information in the study area. These imageries are Landsat 8 OLI (Operational Land Imager) 25 August 2013, Landsat 5 TM (Thematic Mapper) 2 July 2005, Landsat 5 TM (Thematic Mapper) 19 August 1999. The other data consists of RBI (Topographic) map scale 1:25000 from BIG, Geological map scale 1 : 100000 from Geological Agency, Soil map 1:250000 from BBSDLP, Landslide susceptibility map scale 1:25000 from PSDA, Forest area map scale 1:100000 from Ministry of Forestry, Spatial plan map from Bappeda Cianjur regency and Landslide event from local government, reports, newspapers, internet, etc. There were three main step applied in this research, namely: land use analysis, land use change modelling and landslide exposure assessment.

All Landsat imageries which used in this research was obtained from USGS (United States Geological Survey) in level 1T. According to USGS, level 1T was standard terrain correction which provides systematic radiometric and geometric accuracy. In order to check the accuracy of geometric position of the images, a simple overlay of the satellite imageries with topographic map scale 1:25000 as the basis in this study was applied. Based on visual check, the geometric position of the imageries has been coincide with the topographic map. Because of the differences in time of capturing and sensor type, a radiometric calibration was performed for the purpose of change detection process. In this study, a relative calibration method was applied for reducing image brightness difference [Pratisto, 2008; Widiatmoko, 2013]. This method was used by comparing two bands which have the same spectrum, for example band 1 of Landsat 5 and band 2 of Landsat 8.
In order to obtain land use information, a modified of land use classification used by BIG (Indonesian's Geospatial Information Agency) was applied in this research. Land use information was inferred from land cover information obtained from image interpretation [Jansen and Di-Gregorio, 2004; Priyanto, 2010]. Supervised classification using maximum likelihood method was applied in the land cover classification. Training areas for the classification process collected from the knowable area also by support from Google Earth imageries [Priyanto, 2010].

Accuracy assessment of the classification result was calculated using error matrix. The reference data for accuracy assessment process was obtained from fieldwork and coresponding Google Earth [Priyanto, 2010]. The values which calculated from this matrix for accuracy assessment were producer's accuracy, user's accuracy, overall accuracy and kappa statistic.

Change detection method which applied in the analysis was a post classification comparison method. Change analysis will be done by comparing classified images for year 1999 - 2005, 2005 - 2013 and 1999 2013. Land use change modelling was applied in this study in order to predict the land use model for year 2031. The year 2031 was chosen based on spatial plan of Cianjur regency. Furthermore, in this research, CLUE-S [Verburg et al., 2002] was applied to develop the land use model. Because of the land use data have spatial resolution of $30 \times 30 \mathrm{~m}$, the modelling process was also used the same raster size.

CLUE-S model need input from analysis of land use requirements (demand), location characteristics, land use type specific conversion setting, and spatial policies and restrictions [Verburg, 2010]. Figure 2 gives an illustration the input for CLUE-S model. According to the above figure, following are the procedures for developing land use change model in the CLUE-S environment.

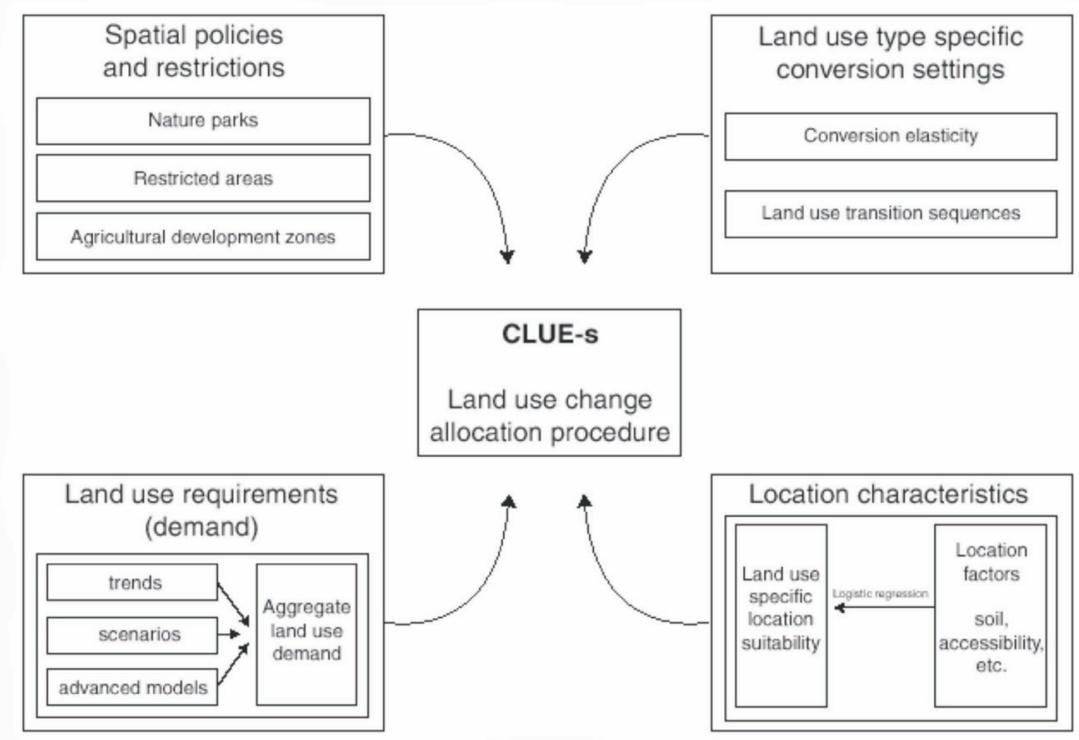

Figure 2. Input for CLUE-S Model [Verburg et al., 2002] 
The identification of driving factors of land use change was conducted in order to obtain underlying factors might influenced land use change in the study area. These factors consist of socioeconomic and biophysical variables, the so-called driving factors, will be used for the analysis in the logistic regression and CLUE-S model [Verburg et al., 2002; Verburg et al., 2007; Priyanto, 2010]. In this research, driving factors of land use change was obtained through a literature review based on related previous research and scientific journal [Cammerer et al., 2012].

Location characteristics denote a set of factors that influence land use changes. These factors will determine the preference of a specific type of land use occurred in a specific location [Priyanto, 2010]. The relation between land use and its possible driving factors was evaluated using binomial logistic regression. The forward stepwise procedure was used in order to select driving factors that have significantly and statistically independent that influenced land use pattern with probability levels of 0.01 for entry in the model and 0.02 for removal from the model [Verburg et al., 2002; Priyanto, 2010]. Driving factors that have no significant contribution to the land use pattern was excluded in the final regression equation. Logistic regression was applied based on sample of $20 \%$ from total dataset available in the grid [Verburg et al, 2002]. The results of the logistic regression are coefficients which describe contribution of each driving factor to the land use pattern and used to create probability map for each land use type. Following is the formula of logistic regression applied in this research.

$$
\log \left[\frac{P_{i}}{1-P_{i}}\right]=\beta_{0}+\beta_{1} X_{12}+\beta_{2} X_{21} \ldots \ldots+\beta_{n} X_{n}
$$

Where:

$\begin{array}{ll}\mathrm{Pi} & \begin{array}{l}: \text { probability for the occurrence of } \\ \text { the considered land-use type }\end{array} \\ \mathrm{X}_{\mathrm{i} . . . \mathrm{n}} \quad: \text { independent variable (driving factors) } \\ \beta \quad: \text { coefficient value }\end{array}$

In order to evaluate the goodness of fit of the logistic regression model, the Relative Operating Characteristic (ROC) was applied [Pontius \& Schneider, 2001]. The ROC value indicates whether the spatial pattern of land use type can be reasonable explained by the independent variables (Priyanto, 2010). A ROC value of 0.5 means a completely random discrimination and a ROC value of 1 a perfect one [Cammerer et al., 2012].

Land use type specific conversion settings determine the temporal dynamics of the model simulations. There are two sets of parameters required to characterize the individual land use types: conversion elasticities and land use transition sequences (Verburg, 2010). Conversion elasticities are used to indicate the reversibility of land use change and provide relative elasticities to change ranging from 0 (easy conversion) to 1 (irreversible change). Land use transition sequences provide a conversion setting for specific land use to determine the temporal dynamic of the simulation by using reversibility of land use change. Value of the conversion matrix consists of 0 and 1 , where 0 mean not allowable conversions and 1 mean allowable conversion.

Spatial policies and restrictions denote areas where land use changes are prohibited through policies or tenure status. The restricted conversion in a specific land use can be described in a land use conversion matrix or by developing restriction map [Verburg et al., 2002; Verburg, 2010]. In this research, spatial policies and restrictions applied as a base for developing scenarios implemented in the land use change model.

The land use requirements constrain the model simulation by determining entailed total area change in land use. According to Verburg [2010], the common technique to calculate land use requirements is by using the extrapolation of trends in land use change of the recent past into the near future. In this research, land use requirement was determined based on land use change analysis result [Priyanto, 2010]. Following is the formula for calculating annual rate of change [Priyanto, 2010].

$A=\left(\left(A_{2}-A_{1}\right) / A_{1} \times 100\right) /\left(T_{2}-T_{1}\right)$

Where:

A : Average annual rate of change (\%)

$\mathrm{A}_{1}$ : Amount of land use type in time $1\left(\mathrm{~T}_{1}\right)$

$\mathrm{A}_{2}$ : Amount of land use type in time $2\left(\mathrm{~T}_{2}\right)$

In order to evaluate the validity of resulted land use map from model simulation, land use map year 2013 from model simulation was compared to land use year 2013, developed from image interpretation, as a reference. This process was calculated the number of equal grid cell in both maps and the pattern similarity of land use. Moreover, kappa statistic which shows degree of similarity of two maps was applied in this step. According to Landis and Koch [1977] cited in Priyanto [2010], kappa values $>80 \%$ is categorized as fit, $60 \%-$ $80 \%$ is high agreement, $40 \%-60 \%$ is moderate and < $40 \%$ is poor.

In order to obtain landslide occurrence data in the study area, landslide inventory approach was applied. Secondary data for landslide occurrence information collected by finding information from local government, newspaper, internet, previous research, and other sources. These data will be checked in the field and mapped. In this research landslide inventory data was used for validation of landslide susceptibility map obtained from PSDA (Water Resource Management Agency) of Cianjur Regency office.

Weighted asset map represent more the relative importance of the assets than an actual measure of their amount [Pellicani et al., 2013]. In this term, the 
relative importance of the assets which located in landslide prone area. The weighted asset map was developed based on the study by Pellicani et al. [2013] with some modifications. In their study, there were four assets, namely social, physical, economic and environmental. However, the assets which considered in this research were only social and physical assets, due to data availability and for future prediction purpose. Population density was applied as a factor for social asset, while land use was applied as a factor for physical asset.

Weight of assets and their factors was determined based on experts opinion by using Analytic Hierarchy Process (AHP) approach. The AHP approach use a pair-wise comparison technique to obtain weight of criteria and factors by using Saaty scale [Saaty, 1987]. Hierarchy of criteria and factors which applied in the AHP approach is shown in Figure 3.

Experts opinion was obtained through interview by using questionnaire. In this research, the experts was choosen purposively by considering their expertise in disaster management and decission making related to spatial planning. The experts came from, planning agency ( 2 people), disaster management agency (1 people), public work agency (3 people), water resource agency (2 people), sub-district government (2 people), village government (3 people) and community in landslide prone area (1 people). Furthermore, for the local government, the choosen respondent was the officer whom their work dealing with disaster occurrence.

Weighted asset map was developed based on land use map and population data. Population data was used for producing population density map. In this research, both data were based on data in year 2013 and prediction data for year 2031. In order to produce weighted asset map for year 2013, land use map was obtained from land use interpretation result and population data was acquired from BPS Cianjur (Statistical Office of Cianjur regency). Furthermore, weighted asset map for year 2031 was developed based on prediction data resulted from scenario-based land use prediction in land use change modeling and population projection data based on statistical data from BPS Cianjur.

Population data obtained from BPS Cianjur were based on per-village population. This data was the result of population cencus in year 1999, 2003, 2006, and 2013. In order to derive future population, a population projection was applied. Following is the formula for population projection [Munibah, 2008]:

$\mathrm{P}_{\mathrm{t}}=\mathrm{P}_{0}{ }^{*} \mathrm{e}^{\mathrm{rt}}$

Where:

$\mathrm{P}_{0}$ : initial population

$\mathrm{P}_{\mathrm{t}}$ : population $\mathrm{t}$ years later

$r \quad$ : annual rate of growth

e : base of the natural logarithm
Mentioned before, obtained population data were in village level, if population density map calculated by using this data, it produce average population density map which assumed population was distributed evenly inside the village boundary. However, in reality population is not distributed evenly inside administrative boundary. Thus, in order to distribute population data, a method developed by Rienow \& Goetzke [2014] was applied in this research. This method disaggregate population based on urban land use (settlement and infrastructure) obtained from land use map. Furthermore, in this research, settlement and infrastructure land use derived from land use interpretation for year 2013 and from future land use prediction using CLUE-S for year 2013.

Population data were dissagregated by using following equation to weight the population in a village based on the sizes of the settlement and infrastructure patches found within that village [Rienow \& Goetzke, 2014].

$P_{i j}=P_{j} / A_{j} \times A_{i j}$

Where:

$P_{i j}$ : Population in an settlement patch $i$ in village $j$

$\mathrm{P}_{j}$ : Population in village $\mathrm{j}$

$A_{j}$ : Area of all settlement patches in village $j$

$A_{i j}$ : Area of settlement patch $i$ in village $j$

Population density was calculated by dividing population number per-settlement patch with its corresponding settlement patch area. A weighting analysis using raster-based calculation in ArcGIS environment was applied for creating weighted asset map. The input for this approach were land use map and population density map. Weight of criteria and factors were based on the result of AHP approach. Following was the formula for the raster-based calculation:

$$
\begin{aligned}
& \text { W= } \sum_{\mathrm{i}=1}^{\mathrm{n}} \mathrm{W}_{\mathrm{i}} \mathrm{x}_{\mathrm{i}} \\
& \text { Where : } \\
& \begin{array}{ll}
\mathrm{W} & : \text { Weighted asset } \\
\mathrm{w}_{\mathrm{i}} & : \text { Weight of factor- } \mathrm{i} \\
\mathrm{x}_{\mathrm{i}} & : \text { Weight of sub-factor- } \mathrm{i} \\
\mathrm{n} & : \text { Number of factor }
\end{array}
\end{aligned}
$$

Weighted asset map was classified into three class of weighted asset, namely high, medium, and low. In order to classify the resulted map, the class interval for classification process applied following formula: Landslide exposure assessment was conducted qualitatively by combining landslide susceptibility map and weighted asset map using two dimensional table described in Table 1.

Analysis of resulted map was conducted by comparing landslide exposure maps year 2013 and year 2031 which based on the scenarios. From this analysis, 
the change or no change of landslide exposed area was identified.

In order to know the implication of scenario-based land use prediction with the established spatial plan, a simple overlay was applied between land use prediction maps and spatial plan map. From this overlay, it can be identified area which are corespond or not correspond with spatial plan. The result from this analysis was combined with the landslide exposure analysis for improving the established spatial plan.

\section{Result and Discussion}

Interpretation of land use in this step was based on process of inferring land use information from land cover classification. There are 12 land cover which can be interpreted from each of Landsat imageries. These land covers are Water body 1 (Areas covered by water), Water body 2 (early phase of paddy field), Built up area, Vegetation 1 (Areas covered by dense trees/forest), Vegetation 2 (paddy plants), Vegetation 3 (cashcrop and vegetable), Vegetation 4 (tea plants), Vegetation 5 (mix of trees from forestry and agricultural plant), Vegetation 6 (shrub and bushes), Barren land 1 (Open land located in the crater of Mt. Gede), Barren land 2 (Paddy field where currently there are no paddy plant), and Barren land 3 (Cash crop and vegetable garden where currently there are no vegetation). Figure 3 shows land cover map resulted from the classification process.

Based on Figure 3, land cover which dominated the study area are vegetation 1, vegetation 3 and built up area. Vegetation 1 consists of areas which have dense vegetation, mainly forest. It is usually located in national park, forest protection area and forest conservation area. Vegetation 3 is the cover type which consists of vegetation located in vegetable and cash crop garden. Built up area is the area which covered by manmade structure.

Land cover map was reclassified in order to obtain land use information. Based on the classification of land use there are six land use in the study area, which are: settlement and infrastructure, forest, wet land farming, dry land farming, tea plantation, mix garden, vacant land and ponds. Figure 4 describes land use map resulted from reclassification process. According to Figure 4, land use in Cipanas and Pacet sub-district are dominated by forest, dry land farming and settlement and infrastructure. Forest has highest proportion of land use in the study area, it is between $30-35 \%$. The second highest land use proportion in Cipanas and Pacet sub-district is dry land farming which has proportion between $26-31 \%$. The third highest proportion of land use is settlement and infrastructure. This type of and use has proportion between $13-18 \%$ of the study area. On the other hand, ponds has lowest proportion with only $0.12 \%$ of the study area. Table 2 shows recapitulation of land use interpretation in Cipanas and Pacet subdistrict year 1999, 2005 and 2013.

Accuracy assessment was conducted for 2005 and 2013 land use information derived from Landsat 52005 and Landsat 8 2013. Reference data for the accuracy assessment were two Google Earth imageries year 2003 and 2013. In addition for the reference data in 2013 there were points of ground truth for accuracy assessment. The 1999 land use classification was not entering the accuracy assessment process because there was no reference data. Accuracy assessment for classification result was conducted based on overall accuracy and Kappa statistic value. The overall accuracy shows percentage of pixels which classified correctly compare to the reference data. The overall accuracy of land use classification based on Landsat 5 year 2005 is $85.71 \%$, and Kappa statistic for this classification result shows value 0.82 . On the other hand, the overall accuracy of land use classification based on Landsat 8 year 2013 is $90 \%$ with Kappa statistic shows value 0.88 . According to Anderson et al. [1976], accuracy of classification process resulted from remote sensing data should be at least $85 \%$. Thus, the overall accuracy on both year 1999 and 2013 have met this criteria. Furthermore, Kappa statistic resulted on both classification results are $>0.8$, this value is classified as fit according to Landis and Koch [1977] cited in Priyanto [2010].

Land use change detection was applied in this research using post classification comparison. Table 3 shows result of change detection. Based on the above analysis, it can be concluded the trend of land use change in the study area as described in Figure 5. Settlement and infrastructure, dry land farming and vacant land have increasing trend. Forest, wet land farming, tea plantation, and mix garden have decreasing trend.

Table 1. Two Dimensional Table for Landslide Exposure Assessment

\begin{tabular}{cccc}
\hline Weighted asset class & \multicolumn{3}{c}{ Susceptibility class } \\
\hline Low & Low exposure & Low exposure & Medium exposure \\
Medium & Low exposure & Medium exposure & High exposure \\
High & Medium exposure & High exposure & High exposure \\
\hline
\end{tabular}


According to Bappeda Cianjur [2012], the sectors that have been able to grow and make a real contribution to the development of Cianjur regency economy are agriculture-plantations, trade and services, and tourism. The areas where these sectors give high contribution to Cianjur regency economy are located in Cipanas and Pacet sub-districts. Almost $40 \%$ of Cianjur regency economic incomes come from these sub-districts.

Based on the above statements, the driving factor of land use change considered in this study are population density, distance to road, distance to river, distance to nearest city, distance to village centre, distance to existing built up area, distance to existing agricultural area, distance to tourism location (socioeconomic driver) and elevation, slope, lithology, soil (biophysical driver).

Generally, land use alterations are expected to be occurred at locations which have the highest 'preference' for a particular type of land use at a given moment [Zheng et al., 2012; Verburg, 2010]. This preference or location characteristic was estimated as probability for each of land use type through logistic regression analysis. Each of land use has their driving factors obtained from logistic regression that depict the influence of each driving factor to the land use change [Priyanto, 2010]. In this analysis, ponds are excluded from the analysis, because they are only cover $12 \mathrm{Ha}$ of the total study area.

The influence of each driving factor is shown by the coefficient $\beta$ resulted in logistic regression. These values depict how much variance from the use of land that can be described by the driving factors. A high positive $\beta$ value indicates a strong positive relationship between driving factors and land use change, while a high negative $\beta$ value indicates a strong negative correlation with land use change [Priyanto, 2010]. Table 4 shows regression coefficient $(\beta)$ resulted from logistic regression analysis.

The goodness of fit of logistic regression was evaluated with the ROC method [Pontius and Schneider, 2001]. In this method, predicted probabilities were compared to the observed values (existing land use)

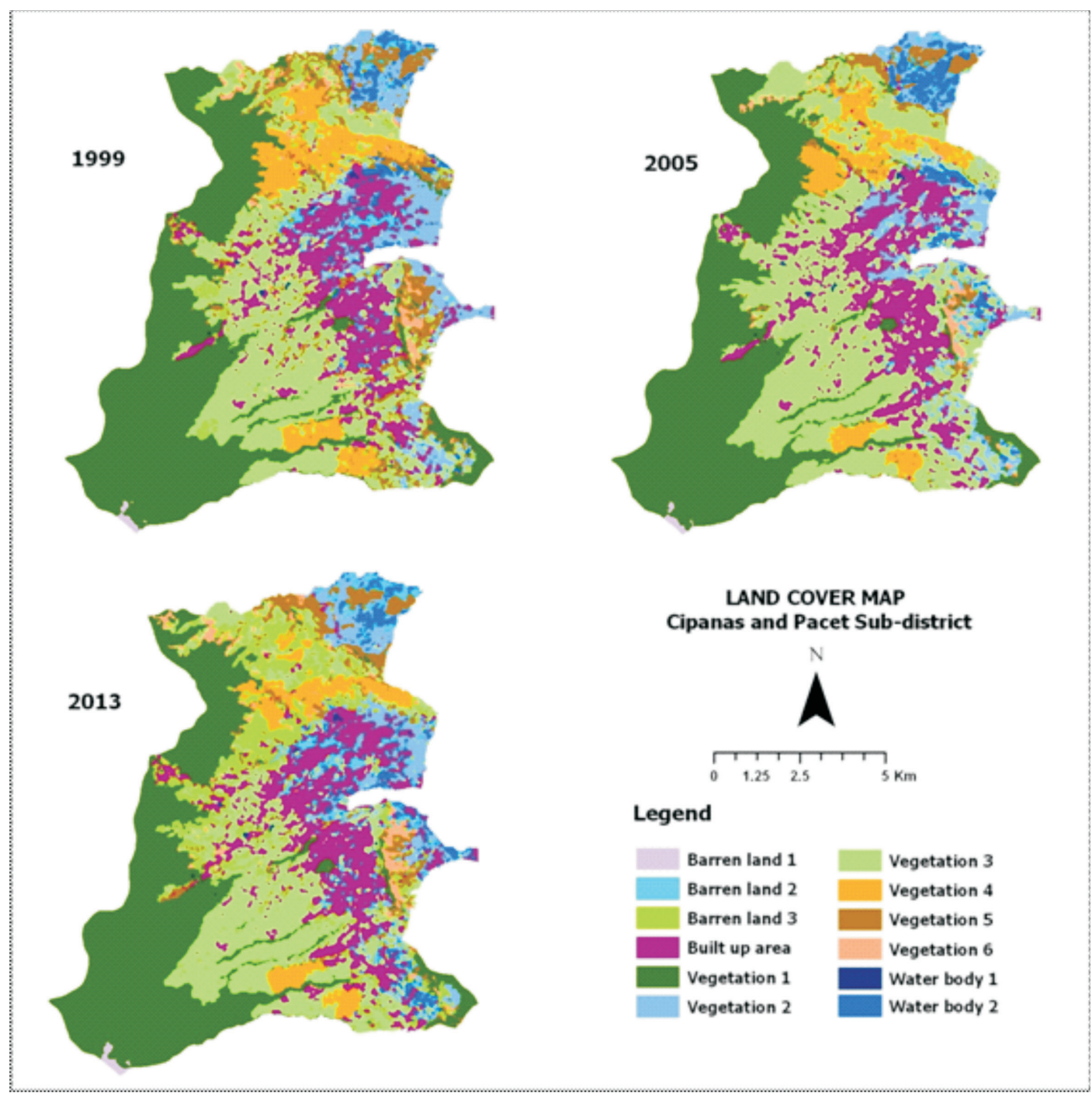

Figure 3. Land Cover Map Year 1999, 2005 and 2013 
and the resulted ROC describe how the regression equation can be applied to predict future land use change according to its probability. An ROC value of 0.5 means a completely random discrimination and a ROC value of 1 a perfect one [Cammerer et al., 2012]. All of the logistic regression has high ROC value, where the highest ROC value obtained for forest land use with the value of 0.973 . On the other hand, the lowest ROC value was obtained for dry land farming with the value of 0.849 . The other ROC value for settlement and infrastructure, wet land farming, tea plantation, mix garden, and vacant land are 0.940, 0.947, 0.955, 0.923, and 0.933 , respectively.

There is no standard method to determine elasticity value [Verburg, 2002]. Furthermore, the CLUE-S user should decide on this factor based on expert knowledge or observed land use behaviour in the recent past [Verburg, 2010]. In order to determine conversion elasticity which used in this research are based on previous research [Kurniawan, 2013; Priyanto, 2010; Warlina, 2009] as a reference and result from field observation during field work.

According to Verburg [2010], land use types with high capital investment will not easily be converted to other land use and it has value of 1 for conversion elasticity. An example of this land use type is settlement and infrastructure; it was because settlement and infrastructure is hard to be converted to another land use type [Priyanto, 2010]. Tea plantation is another example of land use type with high capital investment. In addition, for the reason of conservation value forest has high conservation value which should not be converted to other land use. However, conversion elasticity value for both land use type were not set to 1 . It was because, there were conversion of tea plantation and forest to other land use type occurred in the study area. Therefore, conversion elasticity value for tea plantation and forest were set to 0.9 in order to represent

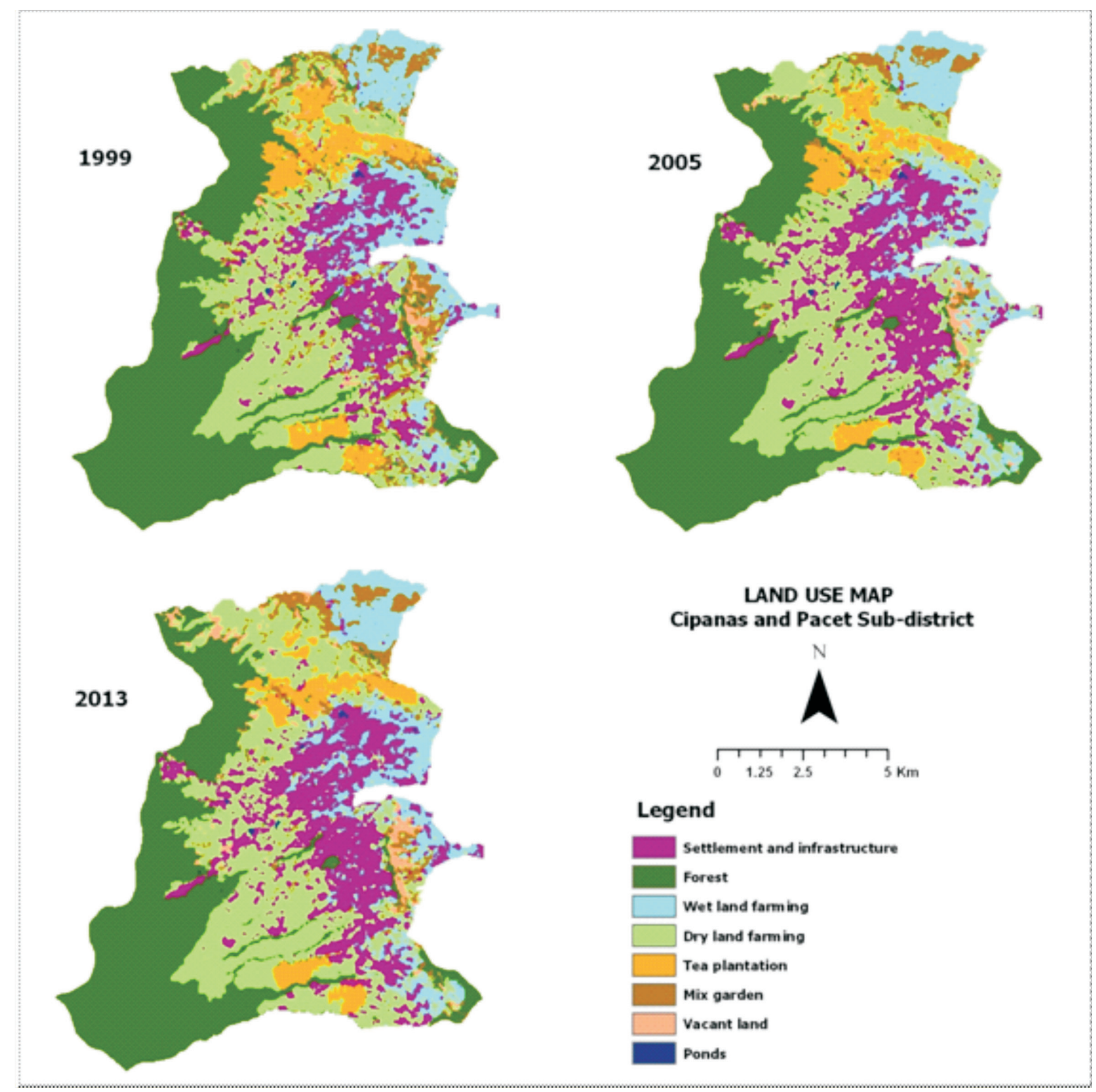

Figure 4. Land Use Map Year 1999, 2005 and 2013 
Indonesian Journal of Geography, Vol. 46 No.2, December 2014 : 104 - 124

Table 2. Land Use in Cipanas and Pacet Sub-district Year 1999, 2005, and 2013

\begin{tabular}{|c|c|c|c|c|c|c|}
\hline \multirow[t]{2}{*}{ Land use type } & \multicolumn{2}{|c|}{1999} & \multicolumn{2}{|c|}{2005} & \multicolumn{2}{|c|}{2013} \\
\hline & $\mathrm{Ha}$ & $\%$ & $\mathrm{Ha}$ & $\%$ & $\mathrm{Ha}$ & $\%$ \\
\hline $\begin{array}{l}\text { Settlement and infra- } \\
\text { structure }\end{array}$ & $1,419.84$ & 13.06 & $1,774.26$ & 16.32 & $2,023.11$ & 18.61 \\
\hline Forest & $3,812.49$ & 35.06 & $3,597.66$ & 33.09 & $3,357.90$ & 30.88 \\
\hline Wet land farming & $1,149.48$ & 10.57 & 990.45 & 9.11 & $1,092.33$ & 10.05 \\
\hline Dry land farming & $2,844.81$ & 26.16 & $3,462.21$ & 31.84 & $3,200.94$ & 29.44 \\
\hline $\begin{array}{l}\text { Tea } \\
\text { plantation }\end{array}$ & 647.91 & 5.96 & 580.23 & 5.34 & 465.12 & 4.28 \\
\hline $\begin{array}{l}\text { Mix } \\
\text { garden }\end{array}$ & 788.76 & 7.25 & 331.65 & 3.05 & 469.98 & 4.32 \\
\hline $\begin{array}{l}\text { Vacant } \\
\text { land }\end{array}$ & 197.64 & 1.82 & 123.75 & 1.14 & 250.83 & 2.31 \\
\hline Ponds & 12.87 & 0.12 & 13.59 & 0.12 & 13.59 & 0.12 \\
\hline Total & $10,873.80$ & 100.00 & $10,873.80$ & 100.00 & $10,873.80$ & 100.00 \\
\hline
\end{tabular}

Table 3. Result of Land Use Change Detection

\begin{tabular}{|c|c|c|c|c|c|c|}
\hline \multirow[t]{2}{*}{ Land use type } & \multicolumn{2}{|c|}{ Change 1999 - 2005} & \multicolumn{2}{|c|}{ Change 2005 - 2013} & \multicolumn{2}{|c|}{ Change 1999 - 2013} \\
\hline & $\mathrm{Ha}$ & $\%$ & $\mathrm{Ha}$ & $\%$ & $\mathrm{Ha}$ & $\%$ \\
\hline $\begin{array}{l}\text { Settlement and infra- } \\
\text { structure }\end{array}$ & 354.42 & 3.26 & 248.85 & 2.29 & 603.27 & 5.55 \\
\hline Forest & -214.83 & -1.98 & -239.76 & -2.20 & -454.59 & -4.18 \\
\hline Wet land farming & -159.03 & -1.46 & 101.88 & 0.94 & -57.15 & -0.53 \\
\hline Dry land farming & 617.40 & 5.68 & -261.27 & -2.40 & 356.13 & 3.28 \\
\hline $\begin{array}{l}\text { Tea } \\
\text { plantation }\end{array}$ & -67.68 & -0.62 & -115.11 & -1.06 & -182.79 & -1.68 \\
\hline $\begin{array}{l}\text { Mix } \\
\text { garden }\end{array}$ & -457.11 & -4.20 & 138.33 & 1.27 & -318.78 & -2.93 \\
\hline $\begin{array}{l}\text { Vacant } \\
\text { land }\end{array}$ & -73.89 & -0.68 & 127.08 & 1.17 & 53.19 & 0.49 \\
\hline Ponds & 0.72 & 0.01 & 0.00 & 0.00 & 0.72 & 0.01 \\
\hline
\end{tabular}

this condition. Conversion elasticity value for wet land farming, dry land farming, mix garden and vacant land were set to 0.5. Based on field observation, these land use types are easier to be converted than settlement and infrastructure, forest, and tea plantation. However, there is no assessment to calculate which land use type is easier to be converted among wet land farming, dry land farming, mix garden and vacant land. Thus, it was assumed that their elasticitities are the same. Value of 0.5 was chosen to represent elasticitities value of wet land farming, dry land farming, mix garden and vacant land were in the middle between 0 (easy conversion) and 1 (irreversible change) [Kurniawan, 2013; Warlina, 2009]. Because pond areas are only cover small area of the study area, conversion elasticity value for this land use type set to 1 . Table 5 shows land use conversion elasticity applied in the model.

Instead of conversion elasticities, in the conversion setting there are also land use conversion matrix applied in the model. This matrix indicates in what other land use type each land use type can change during the period of simulation (Table 6). Values in the matrix are obtained from land use change analysis in the previous step.

According to Presidential Decree No. 54 year 2008 and Bappeda Cianjur [2011], Cipanas and Pacet subdistrict are located in the "Kawasan Strategis Nasional (KSN) Jabodetabekpunjur" (National Strategic Area 


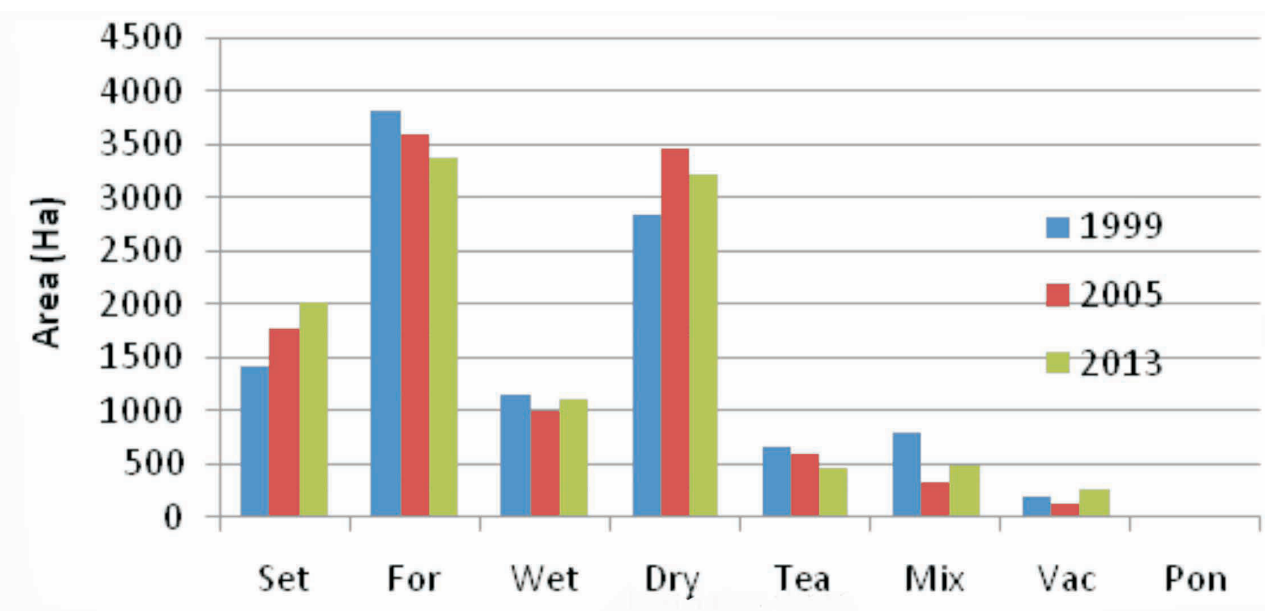

Figure 5. Land Use Change Trend Year 1999 - 2005 - 2013

of Jakarta - Bogor - Depok - Tangerang - Bekasi Puncak - Cianjur). It is stated that developments in this area are focusing for protection and revitalization of conservation area. Based on this statement, in the land use change modeling implementation there is a conversion restriction for existing forest which mainly located in national park and protection forest where forest is not allowed to be converted to another land use. The restriction of forest conversion in conservation area (including national park and protection forest) also stated in the Forestry Enactment No. 41 year 1999.

Tea plantation is assumed to be stable and the area is same with existing tea plantation. It is because tea plantations in the study area are managed by private company which keeping their area for tea production.

Regarding to Bappeda Cianjur [2011], in Cianjur regency's spatial plan there is development restriction in hazard prone area, including landslide prone area. In this study, the development restriction was translated by developing restriction for settlement and infrastructure in landslide prone area. The area that classified as medium and high landslide susceptibility is not allowed for development of settlement and infrastructure.

Spatial policies and restrictions which explained before was applied as the basis for scenario development in the land use modeling. Following were the scenario that applied in this research. Baseline scenario; in this scenario, it is assumed that land use change trends are the same with trend between year 2005 - 2013. Scenario 1 (Restriction in conservation area); in this scenario, there is a conversion restriction for existing forest mainly located in national park and protection forest that are not allowed to be converted to another land use and tea plantation assumed to be stable. Scenario 2 (Restriction in landslide prone area); in this scenario, there is a development restriction for settlement and infrastructure in the landslide prone area. Scenario 2 also applied forest conversion restriction where existing forest mainly located in national park and protection forest are not allowed to be converted to another land use and tea plantation assumed to be stable.
Land use requirement for model simulation was calculated based on land use change analysis by using extrapolation approach. Land use change analysis between 2005 - 2013 was used for land use demand calculation. It was applied in order to minimize difference with recent condition. Also, it was because spatial policies and restrictions used for scenarios development are based on regulation that produced near the recent year, Presidential Decree No. 54 year 2008, Cianjur regency spatial plan year 2011 and landslide susceptibility map year 2010. Table 7 shows land use change annual rate year 2005 - 2013.

In the first part of land use modeling implementation, CLUE-S was run for year 2013 base on initial modeling setting in order to know the accuracy of the land use model. The initial modeling setting apply rate of land use change between 2005 - 2013 without any restriction. Figure 6 show the result for initial model simulation year 2013 together with land use map year 2013 resulted from image interpretation.

Confusion matrix was used for assessing accuracy of the resulted land use model. Land use model was compared to land use map obtained from interpretation process. Overall accuracy obtained from the land use model is 83.13 \% with Kappa value 0.78. According to Koch [1977] cited in Priyanto [2010], the obtained Kappa value was classified as high agreement.

In order to predict future land use, CLUE-S was run for year 2031. This year was chosen for target year because it is correspond with the end of Cianjur regency spatial plan. As mentioned before, prediction for future land use conducted based on three scenarios, namely baseline scenario, scenario 1 and scenario 2 . Figure 7 describes land use year 2031 based on these three scenarios. The figure shows land use prediction by using CLUE-S model gives results what "might" happen in the future in the study area and the spatial pattern of land future land use under certain scenarios.

Land use prediction by considering three scenarios give a result which dominated by settlement and infrastructure expansion. The high expansion occurred 
Table 4. Result of Logistic Regression

\begin{tabular}{|c|c|c|c|c|c|c|c|}
\hline \multirow{2}{*}{$\begin{array}{l}\text { Driving fac- } \\
\text { tor }\end{array}$} & \multicolumn{7}{|c|}{ Land use } \\
\hline & $\begin{array}{l}\text { Settlement } \\
\text { and infra- } \\
\text { structure }\end{array}$ & Forest & $\begin{array}{l}\text { Wet land } \\
\text { farming }\end{array}$ & $\begin{array}{l}\text { Dry land } \\
\text { farming }\end{array}$ & Tea plantation & Mix garden & Vacant land \\
\hline Popdens & 0.442 & & 0.460 & 0.092 & -1.961 & & \\
\hline Elevation & 0.123 & 0.434 & -1.400 & 0.212 & & -0.564 & -0.417 \\
\hline Slope & -0.421 & 0.741 & -0.223 & -0.060 & & 0.637 & 0.531 \\
\hline Roaddist & -0.212 & 0.226 & & -0.134 & -0.127 & 0.132 & \\
\hline Riverdist & 0.126 & -0.463 & -0.215 & -0.129 & 0.460 & 0.226 & 0.188 \\
\hline Citydist & -0.011 & -0.012 & -0.028 & 0.010 & -0.124 & & -0.021 \\
\hline Villdist & & 0.035 & & & & 0.032 & 0.261 \\
\hline Builtdist & -16.854 & -0.101 & & & 0.138 & -0.075 & 0.143 \\
\hline Agricdist & 1.297 & 2.160 & -16.331 & -16.754 & -15.314 & -15.839 & -1.174 \\
\hline Tourisdist & -0.210 & & -0.022 & 0.029 & -0.034 & 0.022 & -0.107 \\
\hline \multicolumn{8}{|l|}{ Lithology } \\
\hline Tuff_sand & & & -0.393 & & & -1.189 & \\
\hline Claystone & & -17.106 & 1.528 & -4.333 & & 0.810 & -2.527 \\
\hline Sandstone & & & 2.565 & -2.119 & 6.670 & & -1.999 \\
\hline Brec_basalt & & 0.648 & 0.763 & 0.558 & 3.802 & & \\
\hline And_breccia & -1.287 & 1.152 & & & -4.382 & & 2.633 \\
\hline And_tuff & 0.488 & 0.976 & 0.377 & -0.647 & 8.649 & & 1.207 \\
\hline Basalt & & 1.485 & & & & 0.690 & \\
\hline \multicolumn{8}{|l|}{ Lahar_lava } \\
\hline \multicolumn{8}{|l|}{ Lava } \\
\hline \multicolumn{8}{|l|}{ Soil type } \\
\hline Dystrudept & & 0.275 & & -0.575 & & & \\
\hline Eutrudept & & & -2.140 & & & -1.448 & -2.355 \\
\hline
\end{tabular}

in the middle part of the study area which corresponds to Cipanas, Cimacan, Sindanglaya, Palasari, Gadog, and Cipendawa villages. It is because these villages have densely settlement area with high population living in the area, also the area located in the centre of Cipanas tourism destination corridor. Generally, this expansion occupies dry land farming located near settlement and infrastructure.

Forest areas in the baseline scenario are decreasing caused by conversion in to another land use. Conversion of forest into settlement and infrastructure occurred in the area where forest bordered with this land use. An example of the area located in Ciloto, Cimacan, and Sindangjaya villages. In this scenario, there are many areas where forest converted into dry land farming, mixed garden and vacant land. It can be seen in northern part of the study area in Batulawang village. Furthermore, forest conversion in this area is the continuation of the past phenomenon.

Landslides which obtained from field work in the landslide inventory activity are only the recent occurrence. It was because there were limited recorded data about landslide occurrence in the study area. Information of landslide occurrence from local government and local people only provide some of the landslide occurrence and occurred in the recent period. There were 70 locations of landslide occurrence obtained in the landslide inventory activity.

Landslide susceptibility map which used for the landslide exposure analysis was obtained from PSDA (Water Resource Management Agency) Cianjur regency office (Figure 8). This map was produced in year 2010 [PSDA Cianjur, 2010]. There are three classes of landslide susceptibility in this map, namely low, medium and high.

In order to validate the map, landslide occurrence derived from landslide inventory applied as reference. This is relative validation base on landslide occurrence observed in the field. Figure 8 shows landslide occurrence overlay with landslide susceptibility map. According to the overlay process, there are 17 landslides located in the high susceptibility area, 47 landslides 
Table 5. Land Use Conversion Elasticities

\begin{tabular}{rr}
\hline Land use type & Elasticities \\
\hline Settlement and infrastructure & 1 \\
Forest & 0.9 \\
Wet land farming & 0.5 \\
Dry land farming & 0.5 \\
Tea plantation & 0.9 \\
Mix garden & 0.5 \\
Vacant land & 0.5 \\
Ponds & 1 \\
\hline
\end{tabular}

Table 6. Land Use Conversion Matrix

\begin{tabular}{|c|c|c|c|c|c|c|c|c|}
\hline \multirow{2}{*}{$\begin{array}{l}\text { Present } \\
\text { land use }\end{array}$} & \multicolumn{8}{|c|}{ Future land use } \\
\hline & Set & For & Wet & Dry & Tea & Mix & Vac & Pon \\
\hline Set & 1 & 0 & 0 & 0 & 0 & 0 & 0 & 0 \\
\hline For & 1 & 1 & 1 & 1 & 1 & 1 & 1 & 0 \\
\hline Wet & 1 & 0 & 1 & 1 & 1 & 1 & 1 & 0 \\
\hline Dry & 1 & 0 & 1 & 1 & 1 & 1 & 1 & 0 \\
\hline Tea & 1 & 0 & 1 & 1 & 1 & 1 & 1 & 0 \\
\hline Mix & 1 & 0 & 1 & 1 & 1 & 1 & 1 & 0 \\
\hline $\mathrm{Vac}$ & 1 & 0 & 1 & 1 & 1 & 1 & 1 & 0 \\
\hline Pon & 0 & 0 & 0 & 0 & 0 & 0 & 0 & 1 \\
\hline
\end{tabular}

Note: Set: Settlement and infrastructure, For: Forest, Wet: Wet land farming, Dry: Dry land farming, Tea: Tea plantation, Mix: Mix garden, Vac; Vacant land, Pon: Ponds

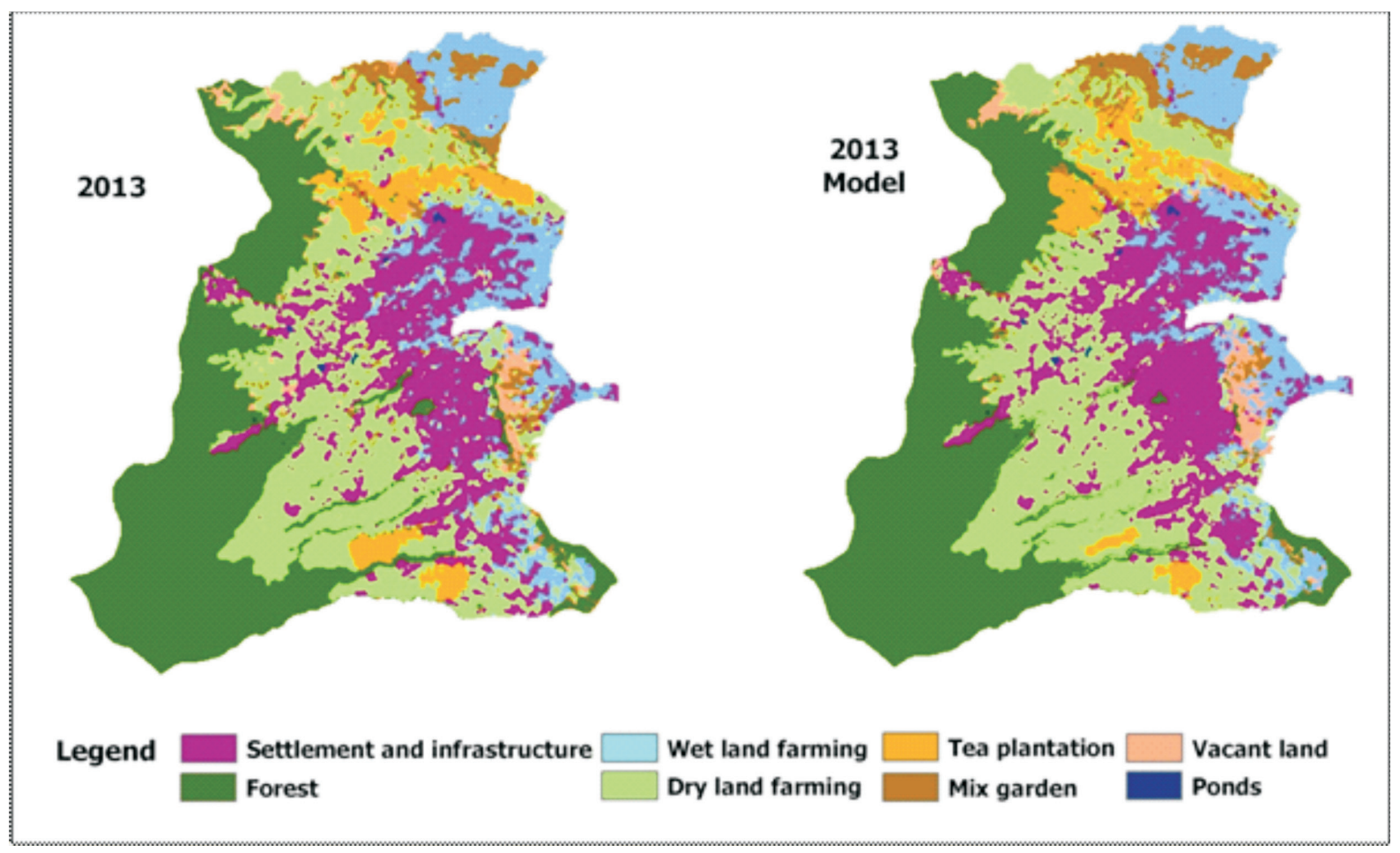

Figure 6. Land Use Map Resulted From Image Interpretation (left) and Initial Model Simulation (right) 
located in medium susceptibility area, and 6 landslide located in low susceptibility area. Based on this relative validation using observed landslide, it can be concluded that the landslide susceptibility map is able to explain landslide occurrence in the field.

Weight of assets was derived by using AHP approach. There were 14 experts who interviewed for this approach. The experts was choosen purposively by considering their expertise in disaster management and decission making related to spatial planning. All of respondent give consistent answer which indicated in Consistency Ratio (CR) value $<0.1$. Table 8 describes weight of criteria and factors obtained from AHP approach.

According to the result of AHP approach, social asset has higher weight (0.57) than physical asset (0.43). This implies that in the study area, social asset has higher relative importance than physical asset. In the social asset, result from the AHP shows the higher the population density the higher its relative importance. It can be seen from the weight of population density class $>25$ people/Ha has highest weight (0.41). Furthermore, in the physical asset, the range of weight of each indicator between are $0.04-0.21$. The highest weight in the physical asset indicator is obtained from settlement and infrastructure (0.21). It implies that settlement and infrastructure has highest relative importance.

Weighted asset map were developed for recent condition in year 2031 and based on prediction for future in year 2031. In order to develop weighted asset map, there were two input data, namely land use and population density map. Furthermore, recent land use map acquired from land use interpretation, while future land use map obtained from prediction using CLUE-S. Population density map was developed based on population data obtained from BPS Cianjur (Statistical office of Cianjur regency).

Future population was calculated by using formula for population prediction. A disaggregation method by Rienow \& Goetzke [2014] was applied for population data distribution. It was because population data obtained from BPS Cianjur were in village level and in reality population is not distributed evenly inside boundary of region. Population density map was developed based on settlement and infrastructure land use obtained from land use interpretation for year 2013 and from future land use prediction using CLUE-S for year 2013. Figure 9 shows population density map resulted from disaggregation method for year 2013 and 2031.

Based on Figure 9, high population density is centered in the middle part of the study area. The area consist of Cipanas, Sindanglaya, Gadog, Palasari, and Sukanagalih. It is the area of dense setllement and infrastructure located around Cipanas and Kota Bunga tourism destination, also centre of trade, sevices and government in Cipanas and Pacet. Future population density map has almost the same pattern, however, the value of maximum population density is different. It was caused by different number and area of patches of settlement and infrastructure which used for disaggregating population data.

A raster-based calculation in ArcGIS was applied for weighting analysis to develop weighted asset map where the weight value of criteria and factor obtained from AHP approach (Table 8). The range value of weighted asset map was between $0.1654-0.3240$. Therefore, in order to classify this map into three classes, interval value of 0.0529 was applied. This interval value obtained from $(0.3240-0.1654) / 3=0.0529$. The result of weighted asset map which has three classes, namely low $(0.1654-0.2183)$, medium $(0.2183-0.2712)$ and high $(0.2712-0.3241)$, was shown in Figure 10 .

According to Figure 10, weighted asset map was influenced highly by pattern of social asset map which developed from population density map. It is because weight of social asset was higher than physical asset in the result of AHP approach. Also, in the physical asset, settlement and infrastructure which applied as the basis for population density map development has the highest weight than other land use. Therefore, the high asset class is located in the middle part of the study area which also corresponds to the area where population density is high and located in settlement and infrastructure land use.

Landslide exposure assessment was conducted by combining weighted asset map and landslide susceptibility map using two dimensional table. The result of this assesment is qualitative landslide exposure map which shows exposure of the asset to the potential landslide occurrence and describe potential degree of damage that will be experienced by asset (Pellicani et al., 2013). Figure 11 shows landslide exposure map for recent condition in year 2013 and for future condition based on the result of scenario-based land use prediction in year 2031.

Based on Figure 11, almost all the village in Cipanas and Pacet sub-district have high landslide exposure area. However, generally, Ciloto and Batulawang villages have more area of high landslide exposure than the other village. It is because these villages have many area which located in high landslide prone area.

Figure 12 also describes change of extent of landslide exposure for recent and future year which quantified by using diagram in Figure 12. There is increasing area of high landslide exposure from year 2013 to year 2031 in baseline scenario and scenario 1 . This area increase from $362.88 \mathrm{Ha}$ to $479.16 \mathrm{Ha}$ in baseline scenario and to $415.17 \mathrm{Ha}$ in scenario 1 . On the other hand, in scenario 2, the high landslide exposure is lower than year 2013 and decreasing to $294.39 \mathrm{Ha}$. While the medium landslide exposure area are increasing from year 2013 to year 2031 in all scenario, the low landslide exposure area are decreasing in this period for all scenario.

According to Figure 9 and 10, increasing area of high landslide exposure in baseline scenario is 
Table 7. Land Use Change Annual Rate

\begin{tabular}{lrrrrr}
\hline Land use type & $2005(\mathrm{Ha})$ & $2013(\mathrm{Ha})$ & Change $(\mathrm{Ha})$ & \multicolumn{2}{c}{ Annual change rate } \\
\hline & & & & $\%$ & Area (Ha) \\
\hline $\begin{array}{l}\text { Settlement and infra- } \\
\text { structure }\end{array}$ & $1,774.26$ & $2,023.11$ & 248.85 & 1.75 & 31.11 \\
Forest & & & & & \\
Wet land farming & $3,597.66$ & $3,357.90$ & -239.76 & -0.83 & -29.97 \\
Dry land farming & 990.45 & $1,092.33$ & 101.88 & 1.29 & 12.74 \\
Tea plantation & $3,462.21$ & $3,200.94$ & -261.27 & -0.94 & -32.66 \\
Mix garden & 580.23 & 465.12 & -115.11 & -2.48 & -14.39 \\
Vacant land & 331.65 & 469.98 & 138.33 & 5.21 & 17.29 \\
Ponds & 123.75 & 250.83 & 127.08 & 12.84 & 15.89 \\
Total & 13.59 & 13.59 & 0.00 & 0.00 & 0.00 \\
\hline
\end{tabular}

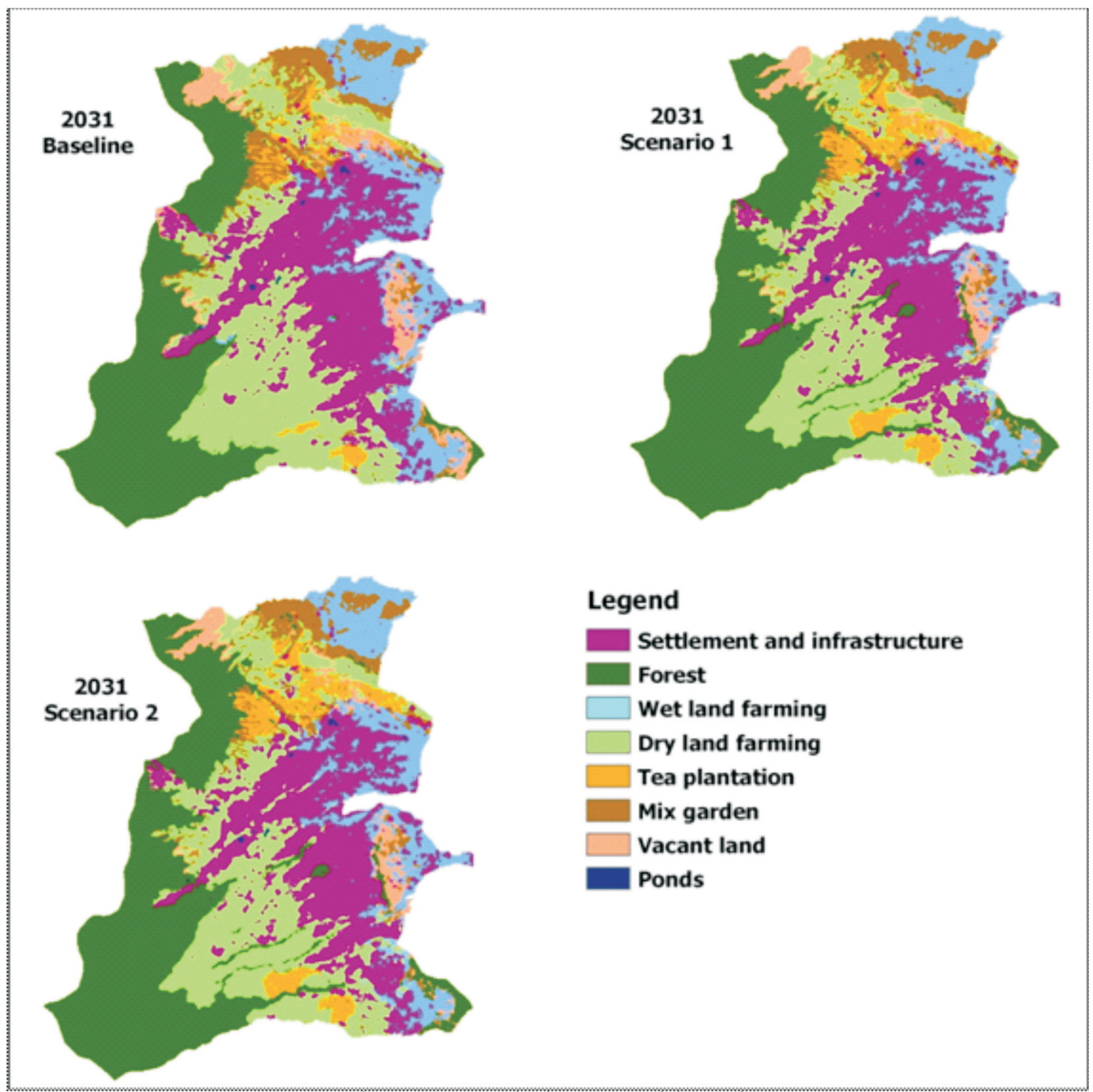

Figure 7. Land Use Map Resulted From Model Simulation Year 2031 


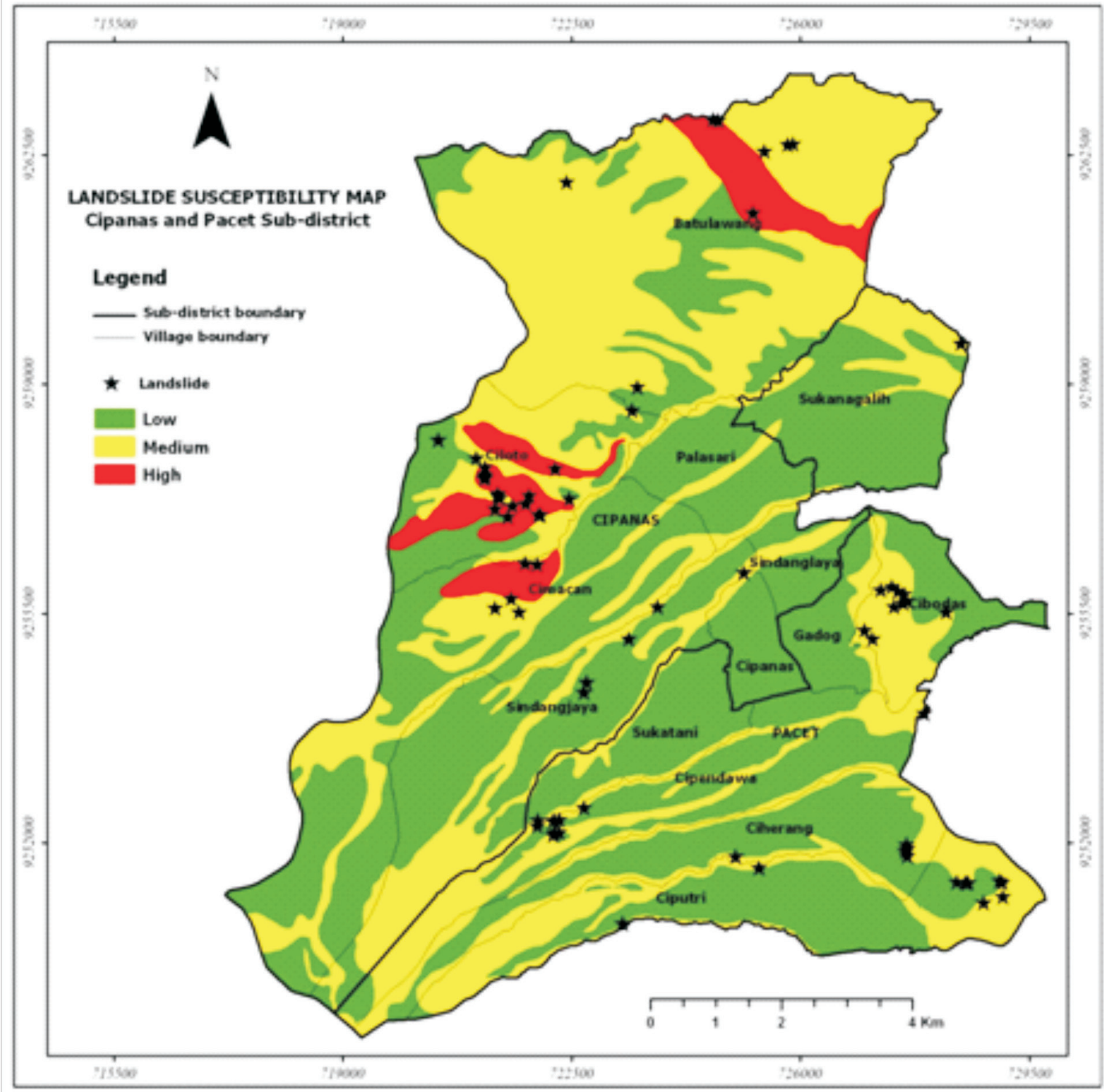

Figure 8. Landslide Susceptibility Map (source: PSDA Cianjur, 2010)

caused by no restriction of conversion in conservation area and new development for settlement and infrastructure. In baseline scenario new settlement and infrastructure occupy area which located in landslide prone area. Furthermore, there is still an increasing high landslide exposure occurred in scenario 1 which apply only conversion restriction in conservation area. The increasing area of high landslide exposure can be minimized in scenario 2 by implementing new settlement and infrastruture development restriction in landslide prone area.

Future prediction resulted from scenario-based land use change modelling using CLUE-S was evaluated with the spatial plan established in the study area. The purpose of this process was to identify areas which are suitable or not suitable with spatial plan. Cianjur regency has established a spatial plan in year 2011 which has validity period for 20 year until 2031. Generally, there are two main land use zone in this spatial plan, namely protected area and cultivation area. Protected area is an area stated for its main function in environmental protection, while cultivation area is an area stated to be cultivated based on the condition and potential of natural resources, human resources and man-made resources. Cipanas and Pacet sub-districts have six land use zone, namely forest protection area, local protection area, forest cultivation area, agricultural cultivation area, and non-agricultural cultivation area [Bappeda Cianjur, 2011]. Figure 13 shows Cianjur regency spatial plan map for Cipanas and Pacet sub-districts.

The evaluation of predicted land use map and spatial plan map was conducted by using two dimensional table. In addition, this evaluation also conducted for recent land use map obtained from land use interpretation for reason of comparison. Summary of the evaluation result described in Table 9.

The result of evaluation reveal that based on the result of land use prediction using CLUE-S there could be a deviation of spatial plan. According to the Table 9, the highest percentage of not suitable area occurred 
in predicted land use using baseline scenario. In the baseline scenario, there were $26.18 \%$ of areas which not suitable to the established spatial plan. Area which not suitable to the spatial plan also occurred in predicted land use using scenario 1 and scenario 2. Percentage of these areas were alamost the same, $22.75 \%$ for scenario 1 and $22.79 \%$ for scenario 2 . However, the percentage of not suitable area in scenario 1 and scenario 2 were lower than baseline scenario. In addition, the areas that were not suitable to the spatial plan has been established since 2013 . These area covered $19.9 \%$ of the study area. Therefore, the potential difference with spatial plan has been recognized since the beginning.

Based on Table 9, the highest not suitable area located in the settlement and infrastructure land use. It can be explained by looking back to the spatial plan map (Figure 13). The area which stated as non-agricultural cultivation area only cover part of recent settlement and infrastructure land use in Cipanas and Pacet subdistrict. Furthermore, settlement and infrastructure land use has been developed outside the stated zone.

Increasing deviation of spatial plan in the future should be a concern. Future land use prediction by using land use change modeling can be used to estimate this deviation. Implementation of scenario in land use change modeling assist identification of potential policy related to restriction development or land use allocation in particular area. Thus, deviation of spatial plan can be minimized.

Related to the landslide exposure assessment, prediction of future land use by using land use change modeling can be applied to assess existance of exposed area in landslide prone area. By assuming continuation of previous trend of land use change and no restriction in the baseline scenario, the existance of high landslide exposure in the study area tend to increase. These areas are mainly located in settlement and infrastructure land use. However, the implementation of conversion restriction for future land use prediction in scenario 1 and scenario 2 can be minimized the existance of high landslide exposure area.

\section{Conclusions}

There were eight land uses in the study area which can be identified from Landsat imageries year 1999, 2005 and 2013, namely settlement and infrastructure, forest, wet land farming, dry land farming, tea plantation, mix garden, vacant land and ponds. Land use in Cipanas and Pacet sub-districts was dominated by forest, dry land farming and settlement and infrastructure. Land use change analysis in this research revealed some patterns of land use change. Settlement and infrastructure, dry land farming and vacant land have increasing trend, while forest, wet land farming, tea plantation, and mix garden have decreasing trend. Based on the identification of land use change driving factors in the study area, there were 12 driving factors, consists of population density, distance to road, distance to river, distance to nearest city, distance to village centre, distance to existing built up area, distance to existing agricultural area, distance to tourism location (socioeconomic driver) and elevation, slope, lithology, soil (biophysical driver). According to the result of logistic regression analysis, the influence of each driving factor to each land use type is shown by the coefficient $\beta$ resulted in logistic regression. There were positive and negative relationships of driving factors to the probability of land use change.

There were three scenario applied in CLUE-S model to predict future land use, namely baseline scenario, scenario 1 (restriction in conservation area), and scenario 3 (restriction in landslide prone area).

Table 8. Land Use Change Annual Rate

\begin{tabular}{|c|c|c|c|}
\hline Criteria & Value & Factors/Sub-factors & \\
\hline \multirow{4}{*}{ Social } & \multirow{4}{*}{0.57} & Population density & Value \\
\hline & & $<10$ people/ha & 0.26 \\
\hline & & $10-25$ people/ha & 0.34 \\
\hline & & $>25$ people/ha & 0.41 \\
\hline \multirow{9}{*}{ Physical } & \multirow{9}{*}{0.43} & Land use & \\
\hline & & $\begin{array}{l}\text { Settlement } \\
\text { \& Infrastructure }\end{array}$ & 0.21 \\
\hline & & Forest & 0.10 \\
\hline & & Wet land farming & 0.18 \\
\hline & & Dry land farming & 0.16 \\
\hline & & Tea population & 0.10 \\
\hline & & Mix garden & 0.11 \\
\hline & & Vacant land & 0.04 \\
\hline & & Water body & 0.11 \\
\hline
\end{tabular}


Baseline scenario assumed that land use change trends are the same with trend between year 2005 - 2013. Scenario 1 restricts conversion in forested area which located in national park and protection forest. Scenario 2 restricts development in the landslide prone area with also restrict conversion in conservation area. Results of scenario-based land use prediction for year 2031 dominated by settlement and infrastructure expansion. This expansion occurred in the middle part of the study area. Forest areas in the baseline scenario were decreasing caused by conversion in to another land use. Furthermore, forest conversion mainly located in the near the border to dry land farming, mixed garden and vacant land use. Implementation of restriction in scenario 1 and scenario 2 in the model was successfully restrict forest conversion into another land use and restricting new development of settlement and infrastructure in landslide prone area.

Land use data can be applied to derive information related to land use itself also as the basis for deriving other information. An example applied in this study was development of population density map which considering settlement and infrastructure land use obtained from land use map. Furthermore, land use data can be applied for the assessment of physical and social asset for developing weighted asset map. The result of recent landslide exposure assessment shows that high and medium landslide exposure area follow pattern of settlement and infrastructure land use. Generally, Ciloto and Batulawang villages have more area of high landslide exposure than the other village. Landslide exposure assessment for year 2031 result shows that high and medium landslide exposure also follow the pattern of settlement and infrastructure. Furthermore, by considering baseline scenario, there is increasing of high landslide exposure area in year 2031. On the other hand, by applying restriction in scenario 1 and 2, high landslide exposure can be reduced. The implementation

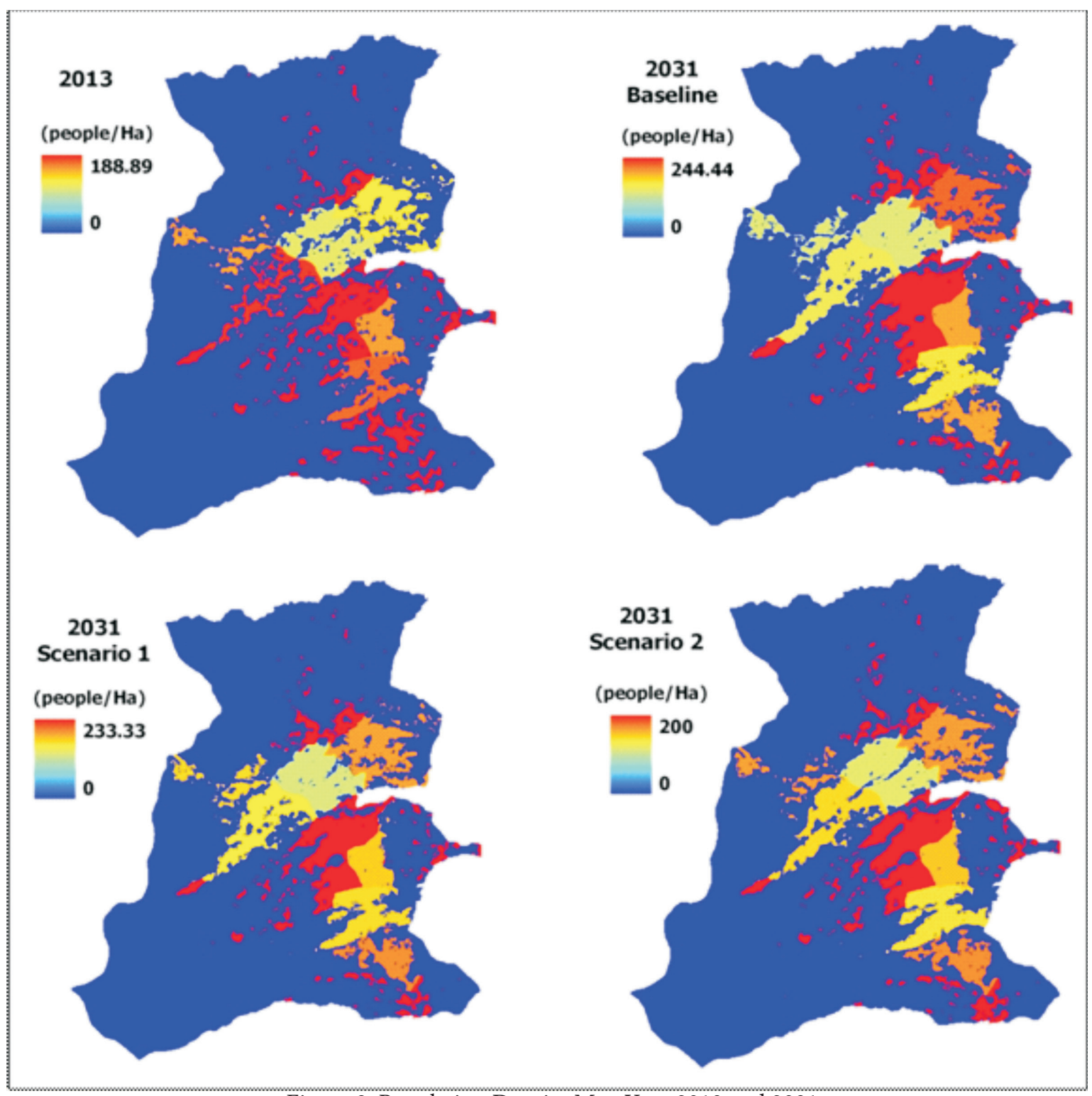

Figure 9. Population Density Map Year 2013 and 2031 


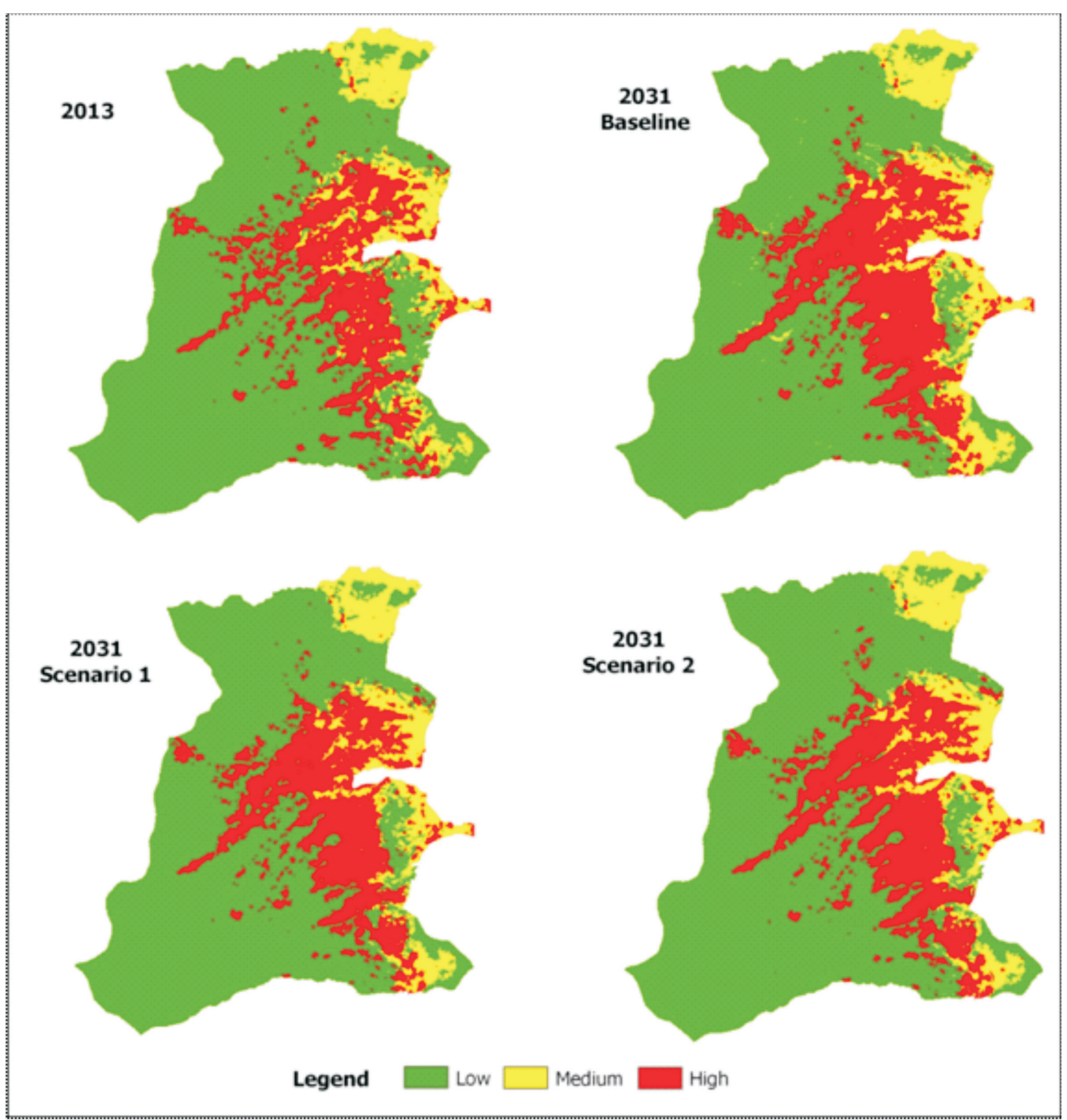

Figure 10. Weighted Asset Map

of scenario-based land use change modelling can be used to identify dynamic of landslide exposure in landslide prone area. The landslide exposure assessment reveal that new development restriction in the landslide prone area will reduce landslide exposure in particular area.

Development restriction for new settlement and infrastructure in lanslide prone has been stated in Cianjur regency spatial plan, however, in reality there are still violations of this regulation. Therefore, the implementation of this restriction have to become major priority in the study area in order to reduce impact of landslide.

Increasing development of settlement and infrastructure outside the non-agricultural cultivation zone in the spatial plan should be a concern. It should be assessed in detail for improving established spatial plan.

The use of detailed land use data in land use change modelling. However, it should be considering CLUE-S limitation which can calculate maximum of $1000 \mathrm{x}$ 1000 pixel data. Thus, the application of other land use model (eg. cellular automata in IDRISI framework) for future land use prediction will be valuable. Assessment of other type of asset (eg. economic and environmental) for complete landslide exposure assessment. 


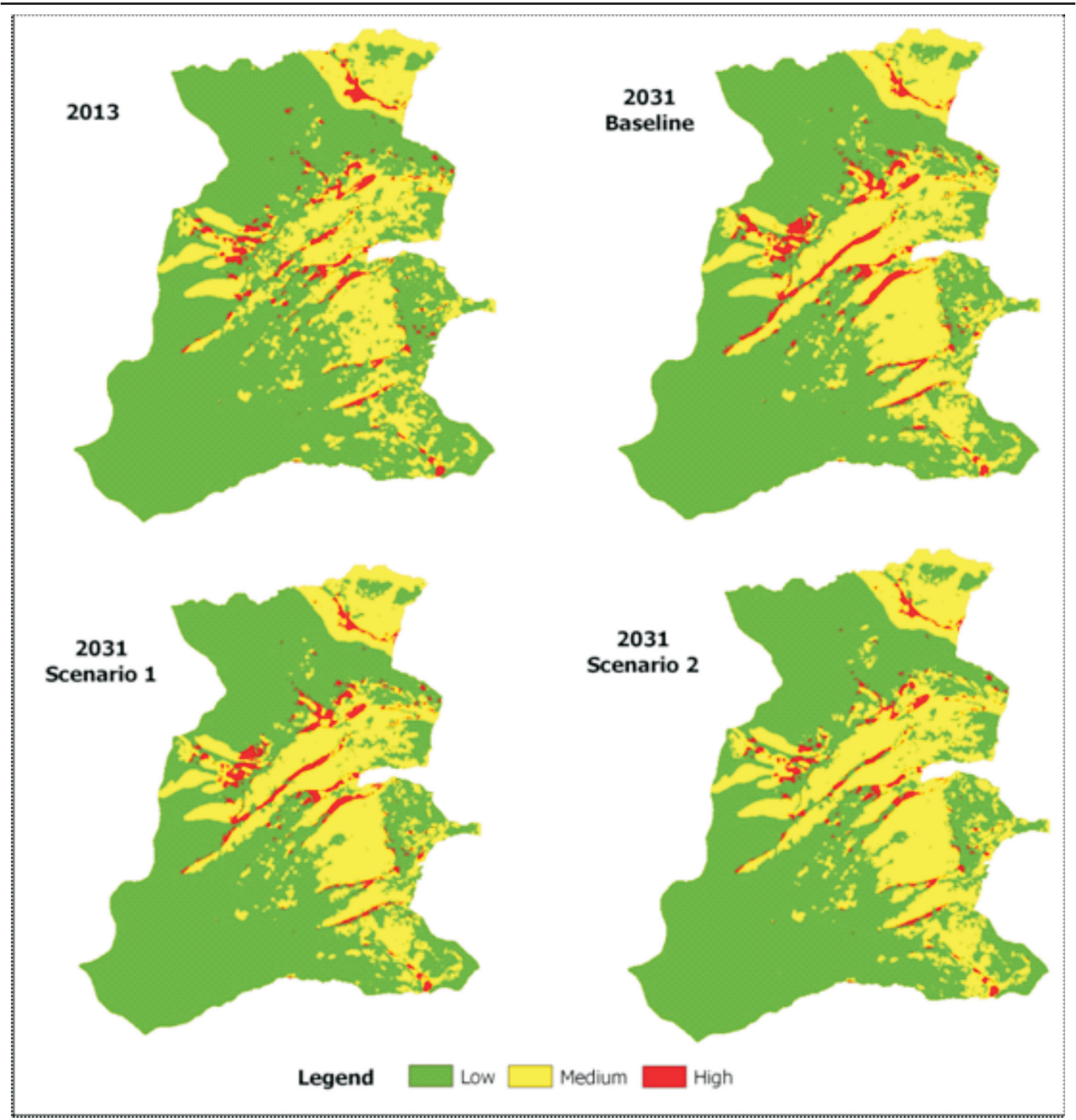

Figure 11. Landslide Exposure Map

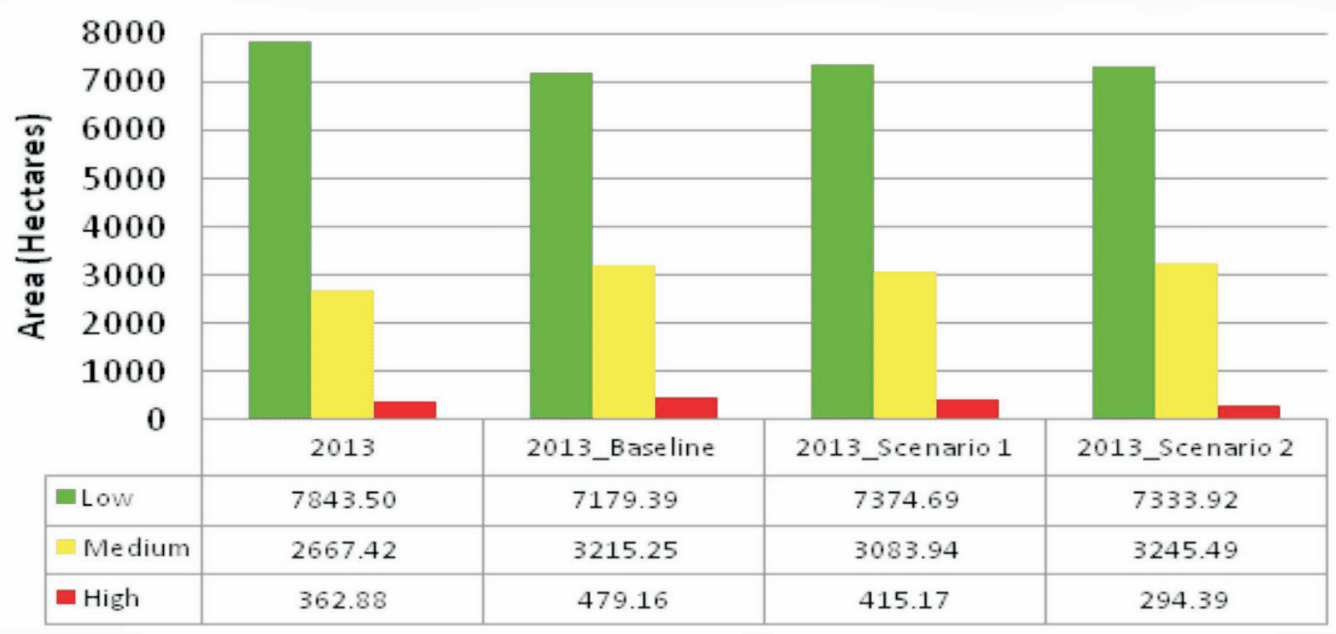

Figure 12. Summary of Landslide Exposure Area per Classes 


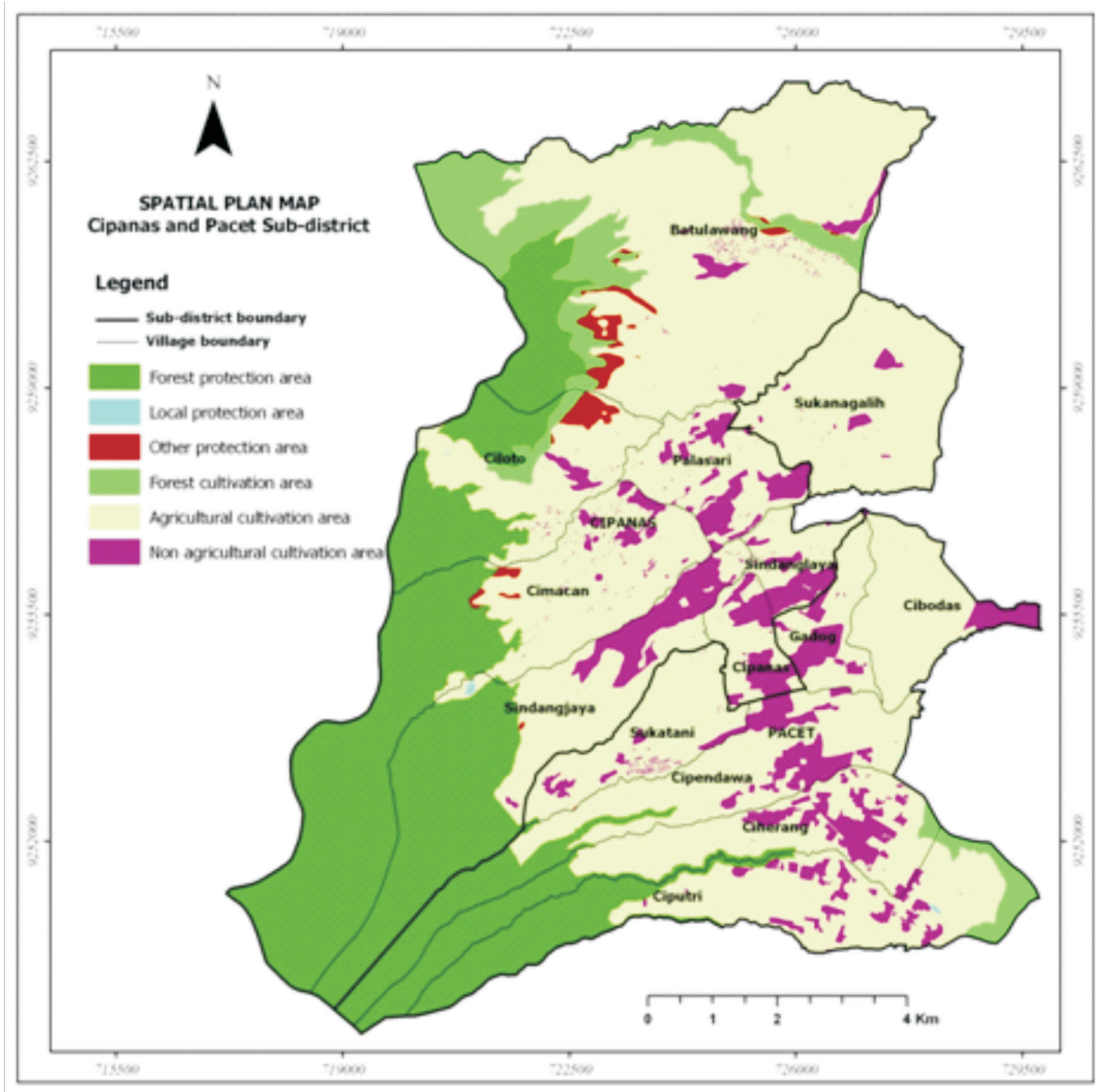

Figure 13. Cipanas and Pacet Sub-district Spatial Plan Map

Table 9. Summary of evaluation result between land use map and spatial plan map

\begin{tabular}{|c|c|c|c|c|c|c|c|c|c|c|}
\hline & Suitability & Set $(\%)$ & For $(\%)$ & Wlf (\%) & Dlf (\%) & Tea (\%) & $\operatorname{Mix}(\%)$ & $\operatorname{Vac}(\%)$ & Pon (\%) & Total (\%) \\
\hline \multirow{2}{*}{$\stackrel{m}{i}$} & Suitable & 5.61 & 30.88 & 9.36 & 24.94 & 4.11 & 3.34 & 1.74 & 0.12 & 80.10 \\
\hline & Not suitable & 12.99 & 0.00 & 0.69 & 4.50 & 0.17 & 0.98 & 0.56 & 0.00 & 19.90 \\
\hline \multirow{2}{*}{ 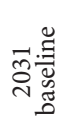 } & Suitable & 6.03 & 26.18 & 11.27 & 19.72 & 1.94 & 5.01 & 3.54 & 0.12 & 73.82 \\
\hline & Not suitable & 17.42 & 0.00 & 0.76 & 4.60 & 0.13 & 2.02 & 1.24 & 0.00 & 26.18 \\
\hline \multirow{2}{*}{ 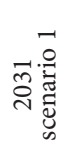 } & Suitable & 5.90 & 31.01 & 10.00 & 18.96 & 4.05 & 4.25 & 2.96 & 0.12 & 77.25 \\
\hline & Not suitable & 16.35 & 0.00 & 0.66 & 3.55 & 0.25 & 1.43 & 0.51 & 0.00 & 22.75 \\
\hline \multirow{2}{*}{ ఠิ } & Suitable & 5.88 & 31.00 & 10.00 & 18.94 & 4.04 & 4.27 & 2.96 & 0.12 & 77.21 \\
\hline & Not suitable & 16.35 & 0.00 & 0.66 & 3.56 & 0.27 & 1.45 & 0.49 & 0.00 & 22.79 \\
\hline
\end{tabular}

Note: Set: Settlement and infrastructure, For: Forest, Wet: Wet land farming, Dry: Dry land farming, Tea: Tea plantation, Mix: Mix garden, Vac; Vacant land, Pon: Ponds 


\section{Acknowledgement}

Thank to Prof. Sudibyakto, M.S for valuable comments and his support during the research and thanks to review for the constructive comments.

\section{References}

Bappeda Cianjur. (2012), Cianjur Regency Spatial Plan year 2011 - 2031 (in bahasa), Development Plan Agency of Cianjur Regency, Cianjur-Indonesia.

BPBD Cianjur. (2012), Landslide susceptibility mapping of Cianjur regency (in bahasa), Regional Disaster Management Agency of Cianjur regency, CianjurIndonesia.

Cammerer, H., Thieken, A. H., \& Verburg, P. H. (2012), Spatio-temporal dynamics in the flood exposure due to land use changes in the Alpine Lech Valley in Tyrol (Austria), Natural Hazards 68(3): 12431270.

Dai, F. C., Lee, C. F., \& Ngai, Y. Y. (2002), Landslide risk assessment and management: an overview, Engineering Geology 64: 65-87.

Hesaki, S. (2012), Land cover/land use analysis in Cibodas biosphere ecology for supporting protection of Gede-Pangranggo Mountain Rang Change 2005 - 2013 (in bahasa), MSc Thesis, Bogor Agricultural University, Graduate School, BogorIndonesia.

Jansen, L.J.M., \& Di-Gregorio, A. (2004), Obtaining land-use information from a remotely sensed land cover map: results from a case study in Lebanon, International Journal of Applied Earth Observation and Geoinformation 5(2): 141-157.

Kurniawan, T. (2013), Spatial modeling of land use changes in relation to spatial planning in the district of Sukabumi (in bahasa), MSc Thesis, Bogor Agricultural University, Graduate School, Bogor-Indonesia.

Pellicani, R., Van Westen, C.J., \& Spilotro, G. (2013), Assessing landslide exposure in areas with limited landslide information. Landslides, 1 - 18. doi: 10.1007/s10346-013-0386-4

Pontius, R. G. \& Schneider, L. C. (2001), Land cover change model validation by ROC method for the Ipswich Watershed, Massachusetts, USA, Agriculture, Ecosystem and Environment 85: 239248.

PSDA Cianjur. (2010), Landslide susceptibility mapping in Cipanas and Pacet sub-districts, Cianjur regency(in bahasa). Cianjur Water Resource Management Agency, Cianjur-Indonesia.
Pratisto, A. (2008). The impact of landcover change on discharge response and flood hazard (A case study in gesing subwatershed, Indonesia), M.Sc Thesis, International Institute for Geo-information and Earth Observation (ITC), Enschede-The Netherlands.

Priyanto, A. T. (2010). The impact of human activities on coastal zones and strategies towards sustainable development: a case study in Pekalongan, Indonesia, M.Sc Thesis, University of Twente Faculty of Geo-Information and Earth Observation (ITC), Enschede-The Netherlands.

Saaty, T.L. (1987), The Analytic hierarchy process what it is and how it is used, Math Modelling 9(3-5): $161-176$.

Verburg, P.H., Soepboer, W., Veldkamp, A., Limpiada, R., Espaldon, V., \& Mastura, S.S.A. (2002), Modeling the Spatial Dynamics of Regional Land Use: The CLUE-S Model, Environ Manage 30(3): 391-405.

Verburg, P.H., Schot, P.P., Dijst, M.J., \& Veldkamp, A. (2004), Land use change modelling: current practice and research priorities, GeoJournal 61: 309-324.

Verburg, P., \& Veldkamp, A. (2004), Projecting land use transitions at forest fringes in the Philippines at two spatial scales, Landscape Ecology 19(1): 77-98.

Verburg, P. H., Kok, K., Pontius, R., Jr., \& Veldkamp, A. (2006), Modeling Land-Use and Land-Cover Change. In E. Lambin \& H. Geist (Eds.), Land-Use and Land-Cover Change, Springer, Berlin.

Verburg, P.H., \& Overmars, K.P. (2007), Dynamic Simulation of Land-Use Change Trajectories with the Clue-S Model, Modelling Land-Use Change 90: 321-337.

Verburg, P.H. (2010), The CLUE modelling framework, Institute for Environmental Studies, University of Amsterdam, The Netherlands.

Widiatmoko, A. (2013), Incorporating landslide susceptibility in land rehabilitation (A Case Study: In Middle Part of Kodil Watershed, Central Java, Indonesia), M.Sc Thesis, Faculty of Geo-Information and Earth Observation (ITC), Enschede-The Netherlands. 